Climate Dynamics

October 2009, Volume 33, Number 5, Pages 685-705

http://dx.doi.org/10.1007/s00382-008-0510-7

(c) 2009 Springer. Part of Springer Science+Business

Media

The original publication is available at http://www.springerlink.com
Archimer, archive institutionnelle de l'Ifremer http://www.ifremer.fr/docelec/

\title{
A model-based study of ice and freshwater transport variability along both sides of Greenland
}

\author{
Camille Lique $^{1,{ }^{*}}$, Anne Marie Treguier $^{1}$, Markus Scheinert ${ }^{2}$ and Thierry Penduff ${ }^{3,4}$
}

\footnotetext{
${ }^{1}$ Laboratoire de Physique des Océans, CNRS-Ifremer-UBO-IRD, Brest, France

${ }^{2}$ Leibniz-Institut für Meereswissenshaften, IFM-GEOMAR, Kiel, Germany

${ }^{3}$ Laboratoire des Ecoulements Géophysiques et Industriels, Grenoble, France

${ }^{4}$ Department of Oceanography, The Florida State University, Tallahassee, FL, USA

*: Corresponding author : C. Lique, email address : Camille.Lique@ifremer.fr
}

\begin{abstract}
:
We investigate some aspects of the variability of the Arctic freshwater content during the 1965-2002 period using the DRAKKAR eddy admitting global ocean/sea-ice model (12 km resolution in the Arctic). A comparison with recent mooring sections shows that the model realistically represents the major advective exchanges with the Arctic basin, through Bering, Fram and Davis Straits, and the Barents Sea. This allows the separate contributions of the inflows and outflows across each section to be quantified. In the model, the Arctic freshwater content variability is explained by the sea-ice flux at Fram and the combined variations of ocean freshwater inflow (at Bering) and outflow (at Fram and Davis). At all routes, except trough Fram Strait, the freshwater transport variability is mainly accounted for by the liquid component, with small contributions from the sea-ice flux. The ocean freshwater transport variability through both Davis and Fram is controlled by the variability of the export branch (Baffin Island Current and East Greenland Current, respectively), the variability of the inflow branches playing a minor role. We examine the respective role of velocity and salinity fluctuations in the variability of the ocean freshwater transport. Fram and Davis Straits offer a striking contrast in this regard. Freshwater transport variations across Davis Strait are completely determined by the variations of the total volume flux (0.91 correlation). On the other hand, the freshwater transport through Fram Strait depends both on variations of volume transport and salinity. As a result, there is no significant correlation between the variability of freshwater flux at Fram and Davis, although the volume transports on each side of Greenland are strongly anti-correlated (-0.84). Contrary to Davis Strait, the salinity of water carried by the East Greenland Current through Fram Strait varies strongly due to the ice-ocean flux north of Greenland.
\end{abstract}

Keywords: Arctic Ocean - Freshwater budget - Freshwater flux - Davis Strait - Fram Strait 


\section{Introduction}

Changes in the Arctic freshwater budget have gained a renewed interest since it is today well admitted that

just a small change of one of its components could strongly affect the World Ocean circulation and thus the climate dynamics. For instance, the Bering Strait freshwater flux may influence the Atlantic Ocean overturning circulation and the Deep Western Boundary Current (Woodgate et al., 2005), and possibly the whole world climate, as suggested by DeBoer and Nof (2004). The freshwater fluxes exiting the Arctic Ocean through Davis Strait and Fram Strait potentially influence the intensity and the timing of the deep convection in the Nordic Seas and the Labrador Sea and then the global thermohaline circulation (e.g., Aagaard and Carmack (1989), Jones and Anderson (2008)).

Many recent studies report drastic changes in the Arctic Ocean during the last decades. For example, Cavalieri et al. (2003) reported from satellite records a large decrease in the sea-ice extent since the early 1980's, while Rothrock et al. (1999) used observations made with submarine-based sonars to document a $40 \%$ decrease in the sea-ice thickness, comparing data during the 1958-1976 period and the 1990's period. At the same time, monitoring of the river discharge from the six major Eurasian rivers revealed a $7 \%$ increase from 1936 to 1999 (Peterson et al., 2002). Changes in the Arctic hydrographic proprieties have also been emphasized. Swift et al. (2005) reported that most of the upper Arctic Ocean became significantly saltier since 1976, although these conclusions suffer from the lack of long term recordings. Some of these changes seem to be closely linked with variability in the atmospheric circulation, whose leading mode of variability is the Arctic/North Atlantic Oscillation (AO/NAO) (e.g., Dickson et al. (2000)). The link between the NAO and the variability of the different components of the Arctic freshwater supply has been investigated in numerous studies. For instance, the NAO influences the sea-ice export through Fram Strait, even though the link may not be robust when we consider long time scales (Vinje, 2000; Kwok and Rothrock, 1999). The NAO could also influence the freshwater storage in the Beaufort Gyre, 
depending on whether the wind circulation regime is cyclonic or anticyclonic (Proshutinsky and Johnson, 1997; Proshutinsky et al., 2002).

Aagaard and Carmack (1989) were the first to provide a complete freshwater budget for the Arctic Ocean. Numerous authors follow this approach, investigating the different components of the budget, including river runoff, exchanges with atmosphere, and the different advective flows of ocean waters and sea-ice through the four pathways (ie, Bering Strait, Fram Strait, the Canadian Arctic Archipelago (CAA) and to the Barents Sea) (e.g., Serreze et al. (2006)). But all these observational works meet the same limitations: the lack of direct observations in the area, due to the harsh winter climatic conditions. Some components of the balance are becoming better observed and estimated, like the sea-ice export through Fram Strait, but most of them remain largely untouched, and their seasonal and interannual variability is still unknown.

Coupled climate models or coupled ocean/sea-ice models have been used to overcome the sparseness of observations. Such models are really useful in that they provide a complete self consistent dataset for analysis. Holland et al. (2006) examined the Arctic freshwater budget in climate model integrations of the twentieth and twenty-first century. They found a important freshening of the Arctic over the two centuries, along with an increase of the ocean freshwater exports to the North Atlantic. Steele et al. (1996) used a simple coarse resolution ocean/sea-ice model of the Arctic Ocean to investigate the freshwater budget over the 1979-1985 period, and found that the ocean freshwater flux through Fram Strait may be out of phase with the flux through the CAA. Maslowski et al. (2004) studied the relative importance of the volume, salt and heat exchanges through Fram Strait and the Barents sea, based on a pan-Arctic ocean/sea-ice $1 / 12^{\circ}$ resolution model. They emphasize the role of the Barents Sea in the import of Atlantic Waters into the Arctic Ocean. Köberle and Gerdes (2003) performed an ocean/sea-ice model simulation over the 19481998 period, in order to study the variations of the Arctic sea-ice content. They underline the wind effects on this variability, and on the sea-ice exports into the North Atlantic. Following an original approach, 
Proshutinsky et al. (2002) and then Häkkinen and Proshutinsky (2004) were probably the first to analyze the variability of the freshwater content in the Arctic. The role of the Beaufort Gyre on the freshwater storage has been investigated in detail, using both observations and ocean/sea-ice model. But their conclusions suffered from the absence of Bering Strait in their coarse resolution model. Moreover, they do not consider Fram Strait and Davis Strait separately, as they focused on the freshwater exports into the North Atlantic. The diversity of model results concerning the Arctic freshwater balance can be seen for instance in Steiner et al. (2004). They compare among other things the freshwater content simulated by the different models of AOMIP (Arctic Ocean Model Intercomparison Project; Proshutinsky et al. (2005)). Gerdes et al. (2008) investigate the Arctic freshwater budget in one of these models, and review the defaults and uncertainties commonly found in Arctic models, as well as their causes and consequences for the representation of the freshwater supply. They underline the critical role of surface conditions and the representation of the different boundaries enclosing the Arctic (the CAA and Bering Strait).

The present study aims at increasing our understanding of the Arctic freshwater budget variability during the last half century. We want to understand the major mechanisms responsible of variations in the Arctic freshwater content. We focus on the ocean freshwater exchanges through the CAA and through Fram Strait, in order to contrast the variability that occurs on both sides of Greenland, both in term of volume and freshwater fluxes. Moreover, the liquid flux and the sea-ice transport are contrasted across these two pathways. To do so, we use a global coupled ocean/sea-ice model. Compared to previous studies, our higher resolution model (between 10 and $13 \mathrm{~km}$ in the Arctic ocean) allows us to represent with an acceptable accuracy the hydrography and the dynamics of the Arctic Ocean, and especially the ocean and sea-ice circulation through the various passages enclosing the Arctic Ocean.

The remainder of this paper is organized as follows. The model and the simulations used for the study are briefly described in section 2 . We validate the model in section 3 , as we consider the mean freshwater 
balance for the Arctic Ocean. The variability of this budget is examined in section 4 in order to determine which components best explain the Arctic freshwater content variability. Circulation and freshwater fluxes across the openings of the Arctic Ocean are described in section 5. In section 6, mechanisms responsible of the interannual variability of the ocean freshwater exports to the subpolar area along both sides of Greenland are investigated. A conclusion is given in section 7.

\section{The Numerical Experiment}

The global ORCA025 coupled ocean/sea-ice model configuration developped in the DRAKKAR project (The DRAKKAR group, 2007) is used to perform the different simulations. An overall description of the model and its numerical details are given in Barnier et al. (2006). This model configuration uses a global tripolar grid with 1442x1021 grid points and 46 vertical levels. Vertical grid spacing is finer near the surface $(6 \mathrm{~m})$ and increases with depth to $250 \mathrm{~m}$ at the bottom. Horizontal resolution is $27.75 \mathrm{~km}$ at the equator, $13.8 \mathrm{~km}$ at $60^{\circ} \mathrm{N}$, and gets to $10 \mathrm{~km}$ in the Arctic Ocean. The ocean/sea-ice code is based on the NEMO framework version 1.9. (Madec et al., 1998). It uses a partial step representation of the bottom topography and a momentum advection scheme which both yielded significant improvements (Penduff et al., 2007). Parameterizations include a laplacian mixing of temperature and salinity along isopycnals, a horizontal biharmonic viscosity, and a turbulence closure scheme (TKE) for vertical mixing. The bathymetry is derived from the 2-minute resolution Etopo2 bathymetry file of NGDC (National Geophysical Data Center). The sea-ice model is the Louvain-la-Neuve model (LIM), which is a dynamic-thermodynamic model specifically designed for climate studies. A detailed description is given in Timmermann et al. (2005).

Our experiment hereinafter referred to as EXP1 is interannual and runs from 1958 to 2002 with no spinup. Initialization is done using data from the Polar Science Center Hydrographic T/S Climatology (PHC; see Steele et al. (2001a) for details). The forcing dataset is a blend of data from various origins at different frequencies (Brodeau et al., 2008). Precipitation and radiation come from the CORE dataset assembled 
by W. Large (Large and Yeager, 2004), at monthly and daily frequency respectively, based on satellite observations when available. A climatology of the same satellite dataset is used for the early years. Air temperature, humidity and wind speed are six-hourly fields from the ECMWF reanalysis ERA40. Turbulent fluxes (wind stress, latent and sensible heat flux) are estimated using the CORE bulk formulae (Large and Yeager, 2004). River runoff rates are prescribed using the Dai and Trenberth (2002) climatological dataset. To avoid an excessive model drift, we add a relaxation of sea surface salinity to the PHC climatology. The coefficient $(0.167 \mathrm{~m} /$ day $)$ amounts to a decay time of 60 days for $10 \mathrm{~m}$ of water depth; under the ice cover restoring is five times stronger. We add extra restoring at the exit of the Red Sea and Mediterranean Sea because those overflows are not adequately represented at that model resolution. A complete description of the experiment is found in Molines et al. (2006). We have chosen to study a 38 year period from 1965 to 2002, excluding this way the first seven years of the simulation when the model adjustment is the most important. For instance, a freshening of the Arctic ocean occurs between 1958 and 1965 (the freshwater content increases by $1.310^{4} \mathrm{~km}^{3}$ between 1958 and 1965). After that, the Arctic properties are more stable even though a model drift still exists (see the evolution of the salinity described in the following section).

In section 6, we use a second experiment (hereinafter referred to as EXP2) run at IFM-GEOMAR (Kiel). This simulation is exactly the same as EXP1 but for three things. The run is forced with pure CORE forcing, which means that air temperature, humidity and wind speed are taken from NCEP rather than ERA 40. The applied relaxation to the PHC climatology of sea surface salinity is weaker, with a coefficient of 300 days for $10 \mathrm{~m}$ of water depth, both at the sea surface and under sea-ice. Finally, a three dimensional restoring to the PHC climatology of salinity and temperature (with coefficient of 180 days) is applied in the polar areas, north of $80^{\circ} \mathrm{N}$ and south of $50^{\circ} \mathrm{S}$. This simulation has been performed for studies of the Tropics and Sub-Tropics areas: therefore, a weak surface relaxation was wanted in these regions while a weaker variability in the polar area was not a problem. The two simulations yield different 
mean states and different variability of the circulation and properties in the Arctic Ocean: this allows us to use EXP2 in section 6 to add robustness to the identified mechanisms of the variability.

\section{The mean simulated Arctic Ocean.}

The aim of this section is to assess the model performances in the Arctic Ocean. We define the Arctic Ocean as the area enclosed by the following transects across ocean straits (Fig. 1): the Bering Strait, a section across the Barents Sea between Norway and Svalbard Island (following the $20{ }^{\circ}$ E meridian), Fram Strait and Davis Strait. Because of the model resolution, there is no link between the CAA and Hudson Bay. We decide to take into account the Arctic Ocean south of the CAA to allow comparison with available data of freshwater transport in Davis Strait (Cuny et al., 2005), the fluxes through the CAA remaining largely unknown and difficult to monitor because of the complex geography (Holland et al., 2006).

As calculations of the freshwater budget depend on two terms (salinity and velocity), we look at the mean salinity profile and the mean circulation over our domain. The averaged salinity profile for our domain is shown in Fig. 2, and compared to the same profile calculated from the PHC climatology data (Steele et al., 2001a). The EXP1 profile is very similar to the PHC profile. The strong observed halocline is well represented, although waters between 300 and 1500 meters get slightly fresher throughout the 38years integration (around 0.1 psu, see Fig. 2). From 1965 to 2002, the 34.8 psu isohaline gets about 200 $\mathrm{m}$ deeper. This is consistent with the corresponding calculated drift of the salinity $(-1,8 \mathrm{mSv})$. Using this salinity as a reference, this small drift represents a gain of $1.110^{3} \mathrm{~km}^{3}$ of liquid freshwater (see appendix for definition), i.e. less than $2 \%$ of the mean freshwater content over the period considered.

The mean surface circulation and ice velocity field are shown in Fig. 3 and 4 respectively. The model reproduces the observed circulation in the Arctic Ocean, as described for instance by Pickard and Emery (1990). A clockwise circulation is visible in the Canadian Basin (the Beaufort Gyre), and, on the other

side of the Lomonosov Ridge, the surface and the sea-ice velocity fields exhibit the Transpolar Drift that 
crosses the Arctic Basin. It seems however that the simulated Beaufort Gyre is displaced closer to the Canadian coast compared to its observed location. Sea-ice velocities are stronger than surface current velocities, but both fields have similar structures. The time series of the Arctic sea-ice extent is shown in Fig. 5. Calculations are done considering the total northern hemisphere as a domain. Model results are in remarkable agreement with NSIDC observations (Fetterer and Knowles, 2002, updated 2004), both in terms of interannual variability and long-term trend, despite a slight underestimation of the time-averaged value.

Our definition of freshwater budget is standard, based on a reference salinity $S_{0}=34.8$ psu (see Appendix for details). The mean values and standard deviations of the components of the Arctic freshwater balance over the 1965-2002 period are listed in Table 1. Runoffs represent the most important freshwater source to the Arctic Ocean. This is due to the presence of many river discharges, chiefly from the drainage of the Ob, Yenesei, Lena and Mackensie. The runoff value used for our simulation (108 mSv) compares well with previous estimates (e.g., Serreze et al. (2006)), but also with values commonly found in numerical experiments (see e.g. Steele et al. (2001b) for the run-off values used in AOMIP models.). Aagaard and Carmack (1989) underline the considerable uncertainty regarding the source of freshwater that the precipitation minus the evaporation represents, and estimate a range of values from 14 to $48 \mathrm{mSv}$. Our model is forced with the precipitation values from the Serreze-Hurst-Yang precipitation climatology (Serreze et al., 2006). In our simulation, precipitation over the Arctic Ocean exceeds evaporation by $69.5 \mathrm{mSv}$ of freshwater in a typical year, and thus the net precipitation represents an important source of freshwater. This value seems to be realistic regarding the area considered and the values published recently (e.g., Dickson et al. (2007)). An extra numerical term has to be taken into account in our freshwater budget: the damping to the climatological sea surface salinity. It represents a mean source of $29.4 \mathrm{mSv}$, i.e. about half the net precipitation term. 
The freshwater transport includes contributions through four pathways, and each contribution is composed of two parts: liquid water and sea-ice. Moreover, we analyze at the same time the volume transport and the liquid and sea-ice freshwater fluxes in order to validate our mean simulated Arctic Ocean. The flux across Bering Strait is a freshwater source for the Arctic Ocean, but the mean value calculated in our simulation is $20 \%$ larger than the observations of $79 \mathrm{mSv}$ from Woodgate and Aagaard (2005). They also estimate the Bering Strait volume throughflow as $0.8 \mathrm{~Sv}$ northward in the annual mean, which is $61 \%$ less than our simulated transport, despite the fact that the two boundary currents are seasonally present in the model as they are observed. The over estimate of the freshwater exchange is thus due to too high velocities across the Strait. The ice transport across Bering Strait is quite small and agrees well with recent measurements by Woodgate and Aagaard (2005).

Observations from Loeng et al. (1997) suggest that 3.3 Sv enter into the Barents Sea while 1.4 Sv are flowing outside, resulting in a net volume transport of $1.9 \mathrm{~Sv}$. The simulated mean net transport through the Svalbard-Norway section is $2.9 \mathrm{~Sv}$, with $4.1 \mathrm{~Sv}$ entering the Barents Sea and 1.2 Sv recirculating back to the Greenland Sea. This means that the flow entering the Arctic Ocean through this section is somewhat larger than observed. Maslowski et al. (2004) obtain similar values and they suggest as an explanation that the discrepancy may be due to the absence of tides in their model, which could be also true in our model. This flux across the Barents Section represents a salt source, i.e. a small sink of freshwater for the Arctic Ocean and its value is yet similar to the $-9.6 \mathrm{mSv}$ considered as representative by Maslowski et al. (2004). The sea-ice transport is somehow larger than the estimate of Kwok et al. (2005b), but the difference could be explained by the different periods considered, as they observe a large range of sea-ice fluxes (e.g., - 7.4 $\mathrm{mSv}$ in 1995 and $-1.0 \mathrm{mSv}$ in 2003), depending on the year considered.

Ocean and sea-ice net transports across Fram Strait and Davis Strait, flowing southward along both sides of Greenland, represent the most important sinks of freshwater for the Arctic Ocean. The ranges of estimates for these contributions are really large and diverse in the literature, as well as the volume trans- 
port estimates. Our simulation results lie within the range of previous estimates (see Table 1) concerning the mean freshwater and sea-ice fluxes. The mean simulated net transports of -2.5 Sv through Davis Strait and -1.8 Sv through Fram Strait are also coherent with observational estimates: Schauer et al. (2008) calculate a 2 Sv southward net transport using 14-16 moorings covering Fram Strait from 1997 to 2006, and Cuny et al. (2005) estimate the net volume transport in Davis Strait between 1987 and 1990 to $-2.6 \mathrm{~Sv}$. A more detailed study of the different branches composing the volume transport through these two pathways is done is section 5 .

Although the simulated Arctic exhibits a few biases as discussed above, the model reasonably represents the large scale circulation, the hydrographic properties and the exchanges with the atmosphere and the subarctic area. The model values compare favorably with previous estimates from direct measurements. This suggests that the model can provide interesting indications on the interannual variability of the Arctic freshwater budget, and insight into the mechanisms that drive this variability.

\section{The interannual variability of the freshwater content and its origins.}

The aim of this section is to analyze the interannual variability of the Arctic Ocean freshwater content over the 1965-2002 period and to determine which components of the Arctic freshwater budget account for this variability.

\subsection{The freshwater content of the Arctic Ocean.}

Häkkinen and Proshutinsky (2004) present one of the few studies of the evolutions of the liquid freshwater content of the Arctic Ocean. They use their model of the Arctic and North Atlantic domain to provide a time series of the Arctic freshwater anomaly for the same period as our study (1950-2000). Köberle and Gerdes (2007) also calculate in their model the times series of the liquid freshwater content in the upper $350 \mathrm{~m}$. These two studies are used for comparison with our own model results. The time series of the Arctic 
Ocean freshwater content anomaly for the EXP1 run is shown in Fig. 6, along with its liquid and sea-ice components. Mean values, standard deviations and linear trends are given in Table 2.

The ice part represents around $25 \%$ of the Arctic freshwater content. The annual means show large variability about the mean state, with a standard deviation of $2140 \mathrm{~km}^{3}$, i.e. $14 \%$ of the long-term mean. In addition to these fluctuations, there is a linear decrease of the Arctic sea-ice volume of $2 \% /$ decade, relative to the long term mean over the 1965-2002 period. These results are consistent with those from previous modeling studies (for instance Hilmer and Lemke (2000) obtain a decreasing linear trend of 4\%/decade over the 1958-1998 period, or 1.8\%/decade over the 1958-1999 period in Fichefet et al. (2003)). A similar trend is also reported in the different papers using satellite based data to study the Arctic sea-ice evolution: e.g., Parkinson et al. (1999) observe a 2.8\%/decade decrease of the Arctic sea-ice extent over the 19781996 period when our modeled sea ice extent time series decreases with a 3.4\%/decade trend.

Our time series of ocean freshwater content is qualitatively similar to the one of Häkkinen and Proshutinsky (2004), with the same maxima (in 1981 and 1988) and minima (in 1977, 1985 and 1995). We also found that our minima are close to ones of Köberle and Gerdes (2007) (around 1977, 1986 and 1997 in their model), but their time series shows a persistent decreasing trend that is not present in our model results. However, this trend is only present for their integration with a constant flux adjustment and not for the similar integration with surface salinity restoring. The ocean freshwater content mean is equal to $5.9610^{4} \mathrm{~km}^{3}$ of freshwater, with a standard deviation of $2.4810^{3} \mathrm{~km}^{3}$, that is about $4 \%$ of the long term mean. The variations are mostly due to time-variations of the different freshwater sinks and sources. An increasing trend is also superimposed to the interannual variability. However, available salinity data in the Arctic ocean are insufficient to determine if this could reveal a natural trend of the liquid freshwater content or if it is totally due to the model drift. 


\subsection{The origins of the freshwater content variability.}

We now examine the interannual variability of the freshwater sources and sinks involved in the freshwater content variability. Häkkinen and Proshutinsky (2004) propose three major processes responsible for variations in the Arctic freshwater storage. The first process they consider is Ekman pumping in the Beaufort Gyre as a cause for the accumulation and release of freshwater. The mechanism is strongly dependent on whether the atmospheric wind is cyclonic or anticyclonic. The second process presented by Häkkinen and Proshutinsky (2004) is the variability of sea-ice growth and melt. But they find that these first two processes have in fact a very weak impact on freshwater content anomalies. The only significant process is the third one: the advective exchanges of water masses between the Arctic Ocean and the subpolar seas. Time series of anomalies of the different components of the Arctic freshwater budget over the 19652002 period for the EXP1 run are shown in Fig. 7. The time series of the freshwater content derivative anomalies are superimposed on each plot for direct comparison. Fig. 8 provides a graphic synthesis of the various terms: their mean value, their standard deviation and their correlation with the time derivative of the freshwater content. Significance level for nonzero correlation are computed from the effective degrees of freedom based on the integral timescales (Sciremammano, 1979). Significance levels as well as effective degrees of freedom (hereinafter referred to as $n$ ) are given in the text and in the different tables.

4.2.1 Surface fluxes. The Arctic river runoff exhibits some interannual variability (Holland et al., 2006) and long-term trend (+7\% over 1936-1999, Peterson et al. (2002)), but their impact on the Arctic freshwater budget was shown to be small compare to changes in sea-ice and liquid freshwater contents (Proshutinsky et al., 2001). The simulation was forced with monthly climatological runoff: its interannual variability has been ignored and this term does not appear in Fig. 7. In the studied area, the model is forced with the precipitation values from the Serreze-Hurst-Yang climatology (Serreze et al., 2006), without interannual variability. The variability in $P-E$ is thus totally due to the variations of the evaporation term. $P-E$ only 
exhibits a weak linear trend of about $0.02 \mathrm{mSv} / \mathrm{decade}$. The standard deviation of this term is small (3.3 $\mathrm{mSv}$ ), and its time variations are not significantly correlated with the variations of the freshwater content derivative. The relaxation to climatological sea surface salinity represents a source of freshwater for the Arctic Ocean. No trend is visible on this component, in agreement with the fact that the model does not drift too much over the considered period (see Fig. 2). But this term is also highly variable, with a standard deviation $(\mathrm{std}=33.2 \mathrm{mSv})$ stronger than the mean value $(29.4 \mathrm{mSv})$. The negative correlation of its variations with the variations of the freshwater content derivative (correlation -0.34 , significance $90 \%, \mathrm{n}=22$ ) indicate that this term damps the variability as expected. Interannual variations of the Arctic freshwater content are thus not caused mainly by surface fluxes, i.e. net precipitations, runoffs and relaxation. We thus turn our attention to the advective fluxes.

4.2.2 The advective fluxes. From 1965 to 2002, the divergence of ocean freshwater fluxes represents an important sink for the Arctic freshwater content variability. No long-term trend is visible over the considered period for this term, but its interannual variations are substantial (std=28.6 mSv, Fig. 7(b)). The variations of this term are highly correlated with the variations of the freshwater content derivative (correlation 0.75 , significance $95 \%, \mathrm{n}=16$ ), showing that the ocean freshwater flux has a leading role in the freshwater content variability. The sea-ice transport divergence (see Fig. 7(a)) exhibits almost the same behavior as the ocean freshwater transport, with no visible trend over the 1965-2002 period, and comparable interannual variability $(\mathrm{std}=22.3 \mathrm{mSv})$. The correlation between its variations and those of the freshwater content derivative is significant as well (correlation 0.52 , significance $95 \%, \mathrm{n}=22$ ).

The variability of the Arctic freshwater content is thus largely controlled by the divergence of advective fluxes, as found by Häkkinen and Proshutinsky (2004) in their model. As the ocean transport and the seaice transport are the sum of four contributions, the exchanges across the four sections need to be examined in order to determine their relative importance. 


\section{Advective fluxes.}

The freshwater balance of the Arctic Ocean has been already calculated from model simulations (e.g., Holland et al. (2006), Köberle and Gerdes (2007), Steele et al. (1996)). However, to our knowledge, this kind of study has never been done using a model with such high resolution (around $12 \mathrm{~km}$ at these latitudes). The most important improvement of our study is probably the better representation of the oceanic circulation across the different sections enclosing the Arctic Basin, and thus of the freshwater exchanges with the North Atlantic and the North Pacific. The contribution across each transect is composed of an inflow and an outflow, this makes the study more complicated since we want to analyze each branch of current separately. The aim of this section is to describe in detail these freshwater exchanges and to determine which contribution has the bigger impact on the Arctic freshwater content variability. Of course our analysis is dependent on the choice of a reference salinity (Appendix 1) and the decomposition of the total advective transport into various branches depends on the volume transport of each branch. For this reason, we will consider both the freshwater and the volume transports. The times series of the ocean and sea-ice freshwater exchanges across the four pathways are shown in Fig. 9. The mean values are also given in Table 3. Correlations between the time series of each component and of the freshwater content derivative are given in Table 4.

\subsection{Bering Strait}

The flux through Bering Strait is a source of freshwater for the Arctic Ocean. The throughflow has strong seasonal and interannual variations, because of the seasonally present boundary currents: the warm and fresh Alaskan Coastal Current (ACC) present in the eastern strait every year at least in summer or in autumn, and the cold and fresh Siberian Coastal Current (SCC) occasionally present in the western Bering Strait. Velocities across the whole strait are highly correlated with the local wind (Woodgate et al., 2005). 
Aagaard and Carmack (1989) estimate the Bering Strait freshwater flux relative to 34.8 psu as $53 \mathrm{mSv}$, and

Woodgate and Aagaard (2005) use long term moorings and ship surveys, from 1990 to 2004, to improve this estimate, adding three contributions: the freshwater advected by the Alaskan Coastal Current (about 7 to $14 \mathrm{mSv}$ ), general stratification of the water column within the strait (about $10 \mathrm{mSv}$ ), and sea-ice advection $\left(3.2_{-}^{+} 2.2 \mathrm{mSv}\right)$. This leads to a new estimate of the freshwater transport: $74 \mathrm{mSv}$ and $3.2 \mathrm{mSv}$ of sea-ice. In the model, the simulated ocean freshwater transport is $28 \%$ larger than observed (see Fig. 9(a) and Table 3), even though the salinity of the Pacific Waters entering into the Arctic Ocean is consistent with the salinity across Bering Strait described by Woodgate et al. (2005) (S seasonally varies from 31.9 to $33 \mathrm{psu}$ ). The simulated sea-ice flux is also larger than the estimate but still within the uncertainty range. The variability of the sea-ice transport is very small $(\mathrm{std}=2.7 \mathrm{mSv}$ ) and thus does not influence the variability of the freshwater storage. The ocean freshwater transport has a larger variability (std $=10.7$ $\mathrm{mSv})$, significantly correlated with the Arctic freshwater content derivative $(\mathrm{r}=0.48$, significance $95 \%$, $\mathrm{n}=29$ ). In our model, this latter flux is the source that has the most important influence on the variability of the freshwater storage, compared with other sources.

\subsection{Barents Section}

Freshwater exchanges are evaluated across the 'Barents Section' $\left(20^{\circ} \mathrm{E}\right)$, between Norway and Svalbard Island. The main inflow of Atlantic Water into the Barents Sea (and thus the Arctic Basin) takes place in the warm, salty Norwegian Atlantic Current entering through the Barents Sea Opening. A percentage of this branch of current recirculates with the cold, Arctic originated, Bear Island Current, and then exiting the Barents Sea. Another source of water to the Barents Sea is the colder and fresher Norwegian Coastal Current, which carries waters originating from the Baltic Sea and Scandinavian runoff eastward. Finally, the last output of water is the cold, fresh East Spitsbergen Current, flowing eastward of Spitsbergen Bank and then with the Bear Island Current. 
The simulated transport across the Barents Section provides a sink of freshwater to the Arctic Ocean. Our simulation results differ from those obtained by Maslowski et al. (2004) with their model as our sea-ice outflow and ocean freshwater outflow have the same order of magnitude, while Maslowski et al. (2004) find a liquid flux about four times higher than the sea-ice flux. Both components of the freshwater flux represent sinks of freshwater for the Arctic Ocean (see Fig. 9(b)), even though the net volume flux brings Atlantic Waters into the Arctic Ocean. But these two sinks of freshwater are negligible regarding the other components of the freshwater budget. No direct measurements of the ocean freshwater input has been done across this section, but our simulated ocean freshwater outflow of $8.1 \mathrm{mSv}$ with a standard deviation of 2.2 mSv seems to agree well with the one obtained by Maslowski et al. (2004) with their model (9.6 mSv). Kwok et al. (2005b) estimate the sea-ice flow across the section using a 10-year record of satellite ice motion and thickness. They show that the flux exhibits a strong interannual variability: the outflow varies from $7.4 \mathrm{mSv}$ in $1994-1995$ to $1.0 \mathrm{mSv}$ in 2002-2003. Our simulated sea-ice outflow exhibits important fluctuations as well, with a standard deviation of about $36 \%$ of the long-term mean. No long term trend are visible for those two fluxes over the considered period. Time series of freshwater transport is significantly correlated with the Arctic freshwater content derivative (see Table. 4), but neither the ocean transport nor the ice transport across the Barents section has large enough variations to influence the Arctic freshwater storage, compared to the other components of the freshwater balance.

\subsection{Fram Strait}

Fram Strait is the only deep-water connection between the Arctic Ocean and the world ocean. It is an important site for the exchange of mass, heat, and salt (Fahrbach et al., 2001). The warm West Spitsbergen Current (WSC) and the ice-infested East Greenland Current (EGC) are the two major currents in Fram Strait. While the WSC carries warm Atlantic waters northward into the Arctic Ocean, the EGC transports cold, fresh water and sea-ice southward out of the Arctic basin (Schlichtholz and Houssais, 1999). 
At around $79^{\circ} \mathrm{N}$ the WSC splits into two branches, because of the complex topography: the first branch flows northward and enters the Arctic Ocean, while the second branch recirculates and then flows southward along the eastern edge of the EGC. The mean circulation and salinity sections are remarkably well represented in the model (see Fig. 11 (c) and (d)), as we compare with observations collected between September 1997 and September 1999 (Fahrbach et al., 2001). The water mass repartition is very similar, with very fresh waters ( $\mathrm{S}$ between 31 and $34 \mathrm{psu}$ ) visible in the upper western part of the section, while the remainder of the transect is more homogeneous ( $\mathrm{S}$ between 34.9 and $34.98 \mathrm{psu}$ ). Simulated velocities are also very coherent with observations. The two branches of current are visible, even though the modeled WSC is slower in the model than in Fahrbach et al. (2001) data $(12 \mathrm{~cm} / \mathrm{s}$ versus $24 \mathrm{~cm} / \mathrm{s})$, and the EGC is stronger than the observed one $(15 \mathrm{~cm} / \mathrm{s}$ versus $9 \mathrm{~cm} / \mathrm{s})$.

Fram Strait is the major exit for the Arctic sea-ice. The budget of Aagaard and Carmack (1989) for the Arctic ocean features a freshwater flux through Fram Strait that is dominated by sea-ice: they estimate that $90 \%$ of the total Arctic sea-ice export exits here, advected by the EGC, and continuously fed by melting along the Greenland Coast. Many authors have estimated the sea-ice contribution to the freshwater transport and its interannual variations (e.g., Vinje (2000), Kwok and Rothrock (1999)), but the ocean contribution remains largely unknown. Meredith et al. (2001) estimated the liquid freshwater flux using sections of oxygen isotopes and the ratio of the meteoric water flux to sea-ice melt. Our simulation provides us with both contributions at the same time, with their interannual variations.

The time series of the simulated sea-ice export across Fram Strait is shown in Fig. 9(d). Over the 19652002 period, $69.1 \mathrm{mSv}$ is exported in the mean from the Arctic, with an important interannual variability $(\mathrm{std}=22.2 \mathrm{mSv})$. Rothrock et al. (2000) summarize estimates of the Fram Strait ice flux available through the late 1990's. These range from $42 \mathrm{mSv}$ to $128 \mathrm{mSv}$, depending on record length and measurement techniques. Our value lies roughly in the middle of this range. No trend is visible in our time series, but the value is highly variable. Three maxima in 1968, 1981-1982 and 1989, and a minimum in 1985 are 
noticeable, and we remark that these extrema are also present in the simulated time series of Haak et al. (2003). They analyze the 1968 maximum as the cause of the observed 70's Great Salinity Anomalies in the Labrador Sea. Nevertheless, our model does not reproduce some of the observed events described for instance by Vinje (2000), such as the large positive export anomaly that occured during the winter $1994 / 1995$.

The time series of volume and ocean freshwater transport anomalies at Fram Strait are shown in Fig. 10. The northward and southward contributions are also indicated. Fahrbach et al. (2001), Schauer et al. (2004) and Schauer et al. (2008) give estimate of the volume transport there, based on current meter moorings, deployed from 1997 to 2006 . They refer for their calculations to the total northward transport as WSC and to the total southward transport as EGC. We take the same convention. Schauer et al. (2008) calculate a volume transport of $12 \mathrm{~Sv}$ to the north and $14 \mathrm{~Sv}$ to the south, the net transport being about $2 \mathrm{~Sv}$ to the south. Simulated volume transports are weaker than these estimates, with a northward component oscillating around 6.5 Sv and a southward component around $8.3 \mathrm{~Sv}$. The mean net transport is 1.8 Sv southward, with a range of variations weaker than 2 Sv. Schauer et al. (2008) estimates are however significantly larger than earlier estimates given in the literature. For instance, Schlichtholz and Houssais (1999) estimate a transport of 1.1 Sv for the WSC and 6.2 for the EGC, which is this time lower than our values.

Due to the lack of measurements across Fram Strait, direct estimates of the ocean freshwater transport are sparse in the literature, and its variability has not been studied before. Meredith et al. (2001) estimate the EGC average freshwater export of $-45 \mathrm{mSv}$, which is much larger than the previous estimate by Aagaard and Carmack (1989) of -28 mSv. Estimate of the WSC contribution is even more uncertain, with observed values ranging from -5 mSv (Aagaard and Carmack, 1989) to -24 mSv (Dickson et al., 2007). Our simulation exhibits a weak mean WSC contribution $(-8.3 \mathrm{mSv})$, the negative sign being explained by waters saltier than 34.8 psu within the WSC. The EGC contribution has an important interannual variability. The mean value $(-54.7 \mathrm{mSv})$ is consistent with Meredith et al. (2001) estimate, and two periods are clearly 
pronounced: a first one between 1965 and 1975 when the freshwater flux is important (around -90 mSv), and a second period between 1985 and 1990 when the flux is weaker (around $-40 \mathrm{mSv}$ ). No estimates of the long term variability has been done before, so it is difficult to determinate if this contrast between the two periods is realistic or just a model artifact. The variability of the net freshwater flux through Fram Strait is clearly controlled by the export branch, as the inflow has a weaker influence on the variability (see Fig. $10(d))$.

Fram Strait is the only pathway where the mean ocean freshwater transport and sea-ice transport have the same order of magnitudes (respectively $-63.1 \mathrm{mSv}$ and $-69.1 \mathrm{mSv}$ ), the same amplitude of variation (respectively std $=16.2 \mathrm{mSv}$ and $\mathrm{std}=22.2 \mathrm{mSv}$ ), and the variations of the two terms are as much correlated with the variations of the freshwater content derivative (respectively $r=0.42$, significance $90 \%$, $\mathrm{n}=15$ and $\mathrm{r}=0.45$, significance $95 \%, \mathrm{n}=21$ ). This shows that both terms strongly influence the variations of the Arctic freshwater storage. However, the variations of the two terms are not significantly correlated with one another.

\subsection{Davis Strait}

The Canadian Arctic Archipelago is a large and complex system of channels through which an important part of the Arctic freshwater export flows. Because of our limited model resolution, there is no link between the CAA and Hudson Bay, so all the freshwater flux exiting the Arctic Ocean will enter in the Labrador Sea through Davis Strait, where direct measurements of the freshwater transport exist (Cuny et al., 2005). The mean flow across Davis Strait is similar to the mean flow across Fram Strait, with two branches of current flowing in opposite directions. As it enters into the Labrador Sea near Cape Farewell in the South of Greenland, the EGC becomes the West Greenland Current (WGC) and flows northward along the Greenland Coast. When it crosses the 670 meters deep Davis Strait, it splits into two branches: the main one recirculates westward with the Labrador Current, while another branch enters the Baffin Bay. On the 
west part of the Strait, cold and fresh water flows south from Baffin Bay with the Baffin Island Current (BIC). Cuny et al. (2005) studied hydrographic proprieties, volume and freshwater transport across Davis Strait, based on ship surveys and moorings deployed across the section from September 1987 to August 1990. The mean simulated salinity section (Fig. 11 (a)) agrees well with the observations of Cuny et al. (2005): we find low salinity layers in the upper part of the section. The most important difference with observations is that the waters in the eastern part of the strait are slightly saltier in the model. The mean circulation across Davis Strait is correctly represented as well (Fig. 11 (b)). Indeed, the two current veins exist in our simulation and the vertical structures are realistic. On the WGC, model velocities reach 10 $\mathrm{cm} / \mathrm{s}$, i.e. slightly less than observed $(15 \mathrm{~cm} / \mathrm{s})$. It is also true in the BIC, where the maximum simulated speeds are $5 \mathrm{~cm} / \mathrm{s}$ weaker than observed $(15 \mathrm{~cm} / \mathrm{s}$ against $20 \mathrm{~cm} / \mathrm{s})$.

The time series of the simulated sea-ice export across Davis Strait is shown in Fig. 9(d). Cuny et al. (2005) assumed that the sea-ice transport through the Canadian Archipelago and then Davis Strait is negligible, because the sea-ice is mostly land-fast. They estimated the sea-ice freshwater transport to $-12.9 \mathrm{mSv}$. Our simulated ice flux is a bit larger, with a mean value of $-17.1 \mathrm{mSv}$, and weak variations $(\mathrm{std}=3.8 \mathrm{mSv})$. As we did for Fram Strait, we decide to attribute the total northward transport to the WGC, and the southward transport to the BIC. The time series of volume and ocean freshwater transport anomalies across Davis Strait are shown in Fig. 10. The northward and southward contributions are also indicated. The net volume and ocean freshwater fluxes are dominated by the southward contributions, the mean WGC fluxes and their variations being negligible. Mean values agree well with estimates from Cuny et al. (2005) (a transport of $1.2 \mathrm{~Sv}$ and a freshwater transport of $38 \mathrm{mSv}$ ). The weaker freshwater transport is explained by higher salinity due to a salty bias in the upper Labrador Sea, also found in many other models (Treguier et al., 2005). The volume and ocean freshwater transported by the Baffin Island Current (respectively 3.7 Sv and $137.6 \mathrm{mSv}$ ) exhibit important and similar interannual variability. These transports agree well with estimates of Cuny et al. (2005) and Loder et al. (1998), who respectively measure volume transport 
of -4.6 Sv and -3.3 Sv, and freshwater transport of $152 \mathrm{mSv}$ and $120 \mathrm{mSv}$. The differences between the observations and our simulation are due to slower currents across the section. No long-term trend is seen on these fluxes, but the interannual variations are important, reaching $30 \mathrm{mSv}$. As for Fram Strait, the variability of the net freshwater flux is also controlled by the variations of the freshwater export by the BIC (see Fig. 10 (b)).

Unlike at Fram Strait, the total freshwater export through Davis Strait is due to the ocean freshwater flux, the sea-ice transport being negligible. The ocean freshwater flux has a comparable influence on the Arctic freshwater content as the ocean flux through Fram Strait, as their amplitude of variations and their correlation with the freshwater content derivative are similar.

\subsection{Discussion.}

Finally, the advective flux that drives the variability of the Arctic freshwater content is dominated by four single components (see Fig. 8). In our model, the ocean transport through Bering Strait is the only source of freshwater with an important interannual variability. The freshwater stored in the Arctic Ocean is then mostly exported to the Nordic and Labrador Seas, across Fram Strait (as liquid freshwater and sea-ice) and Davis Strait (mostly as liquid freshwater). As we compare the times series of the liquid freshwater fluxes across the four sections (see Fig. 12 (b)), it seems that the most important variability is found across Fram and Davis Straits. Nevertheless, no significant correlation exists between the freshwater fluxes across the two sections. Furthermore, variations of the Pacific freshwater import through Bering Strait are not correlated with variations of the total freshwater flux exiting to the North Atlantic (through Davis and Fram Straits and the Barents section). Explanation of this absence of correlation could be then that the waters entering the Arctic Ocean are modified (become fresher) before they exit the Atlantic. To confirm this idea, we look at the time series of the volume flux anomaly across the four sections (Fig. 12 (a)). As expected from mass conservation, variations of the total flux exiting toward the North Atlantic are 
highly correlated with those at Bering Strait (correlation -0.97 , significance $95 \%, n=23$. The minus sign is explained by our transport sign convention, where a source of water for the Arctic Ocean is a positive value.). This reflects a rapid adjustment by fast surface waves rather than an advective process, since no significant lag is found when the correlation is calculated using monthly time series.

\section{Mechanisms driving the interannual variability of the Arctic ocean freshwater export.}

The remainder of the study will be focused on the freshwater export along both sides of Greenland, i.e. across Fram and Davis Straits, as they are the two most important sinks of freshwater for the Arctic Ocean. As the sea-ice transport is negligible across Davis Strait and well known and observed across Fram Strait, we will concentrate on the liquid part of the freshwater flux. We will try to identify the mechanisms responsible of the interannual variability of these two fluxes.

\subsection{Davis versus Fram.}

Steele et al. (1996) investigated the freshwater balance of the Arctic Ocean over a short period (19791985) with an ocean/sea-ice model. They found that the freshwater outflow through the CAA tends to compensate for the ocean freshwater outflow across Fram Strait, with a one year lag. Since this result is obtained for a very short period, concern about the model dependency is probably legitimate. No significant correlation or anti-correlation can be found between monthly ocean freshwater fluxes through Davis Strait and Fram Strait in our simulation for lags ranging from -5 to 5 years. However volume transport variations along both Greenland sides are strongly anti-correlated $(r=-0.84$, significance $95 \%, n=14)$ at zero lag. Moreover, since these two fluxes exhibit similar variations (std $=0.37 \mathrm{~Sv}$ for Davis Strait and std $=0.42 \mathrm{~Sv}$ for Fram Strait), the total volume export from the Arctic Ocean along both sides of Greenland remains almost constant in time. This anti-correlation could find its origin in the large-scale wind-forced cyclonic circulation around Greenland calculated by Joyce and Proshutinsky (2007), as they apply God- 
frey's Island Rule to Greenland. It thus seems that the total ocean freshwater export and the total volume export are not strongly linked, unlike at Davis Strait where a high correlation was found between both fluxes ( $\mathrm{r}=0.97$, significance $95 \%, \mathrm{n}=13$ ). To check whether this result is model dependent, we use the EXP2 run presented in section 2. The correlation between the ocean freshwater flux and the volume flux across Davis Strait is also very high in this simulation ( $r=0.90$, significance $95 \%, \mathrm{n}=17)$. The fact that the Davis Strait transports of the two experiments are correlated ( $\mathrm{r}=0.90$, significance $95 \%, \mathrm{n}=16)$ suggests furthermore that the variability is forced by the atmosphere and does not result from purely oceanic nonlinear instabilities or modes of variability, which would be uncorrelated between the two experiments. In contrast, the ocean freshwater flux and the volume flux across Fram Strait are not significantly correlated in both runs. The ocean freshwater flux variability across Davis Strait thus seems to be controlled by the variability of the volume transport, i.e. the velocity across the section, while the ocean freshwater flux variability at Fram Strait seems to be controlled by variations in the salinity distribution. This hypothesis is tested in the following.

\subsection{Analysis of freshwater fluxes.}

Freshwater fluxes depend on salinity and velocity fields. We want to determine which one of the two terms control the time variability of the freshwater transport. The fluxes across the different pathways can be broken down into different components.

We write velocity and salinity as:

$$
\left\{\begin{array}{c}
v=\bar{v}+v^{\prime} \\
S=\bar{S}+S^{\prime}
\end{array}\right.
$$

with $\bar{v}$ and $\bar{S}$ being the time-averaged velocity and salinity, and $v^{\prime}$ and $S^{\prime}$ being respectively the deviations from these averages. The freshwater flux can be separated into four terms as follows:

$$
T_{F W}=\iint\left(\bar{v}+v^{\prime}\right) \frac{S_{0}-\left(\bar{S}+S^{\prime}\right)}{S_{0}} d A=\iint \bar{v} \frac{S_{0}-\bar{S}}{S_{0}} d A-\iint \bar{v} \frac{S^{\prime}}{S_{0}} d A+\iint v^{\prime} \frac{S_{0}-\bar{S}}{S_{0}} d A-\iint v^{\prime} \frac{S^{\prime}}{S_{0}} d A
$$


As we note

$$
S_{1}=\frac{S_{0}-S}{S_{0}}
$$

we have

$$
\left\{\begin{array}{c}
\overline{S_{1}}=\frac{S_{0}-\bar{S}}{S_{0}} \\
S_{1}^{\prime}=-\frac{S^{\prime}}{S_{0}}
\end{array}\right.
$$

and then obtain:

$$
T_{F W}\left(v, S_{1}\right)=T_{F W}\left(\bar{v}, \bar{S}_{1}\right)+T_{F W}\left(\bar{v}, S_{1}^{\prime}\right)+T_{F W}\left(v^{\prime}, \bar{S}_{1}\right)+T_{F W}\left(v^{\prime}, S_{1}^{\prime}\right)
$$

Fig. 13 shows the anomalies of the various contributions to the ocean freshwater transport across Davis Strait and Fram Strait, in both runs. Means and standard deviations of each term are given in Table 5, as well as correlations of each contribution with the ocean freshwater flux.

Fig. 13 shows that the quadratic term $T_{F W}\left(v^{\prime}, S_{1}^{\prime}\right)$, calculated from monthly output, is stronger across Davis Strait than across Fram Strait (meanly -10,4 mSv and -1,4 mSv for the EXP1 run) but with similar standard deviations (below $3 \mathrm{mSv}$ ). In both runs and at both straits, quadratic components thus have a negligible contribution to the freshwater flux mean and variability.

A contrast between Fram Strait and Davis Strait appears clearly. Across Davis Strait, $T_{F W}\left(v^{\prime}, \bar{S}_{1}\right)$ anomalies are two times stronger than $T_{F W}\left(\bar{v}, S_{1}^{\prime}\right)$ anomalies in EXP1, and more than four times in EXP2 run. Across Fram Strait, both anomalies have the same order of magnitude (std around 9,8 mSv for the EXP1 run). $T_{F W}\left(v^{\prime}, \bar{S}_{1}\right)$ anomalies are correlated at 0.95 with the total ocean freshwater flux anomalies at Davis Strait, and only at 0.8 across Fram Strait (see Table 5). This analysis confirms that freshwater flux anomalies are mainly controlled by velocity anomalies at Davis Strait and by the variations of both salinity and velocity distributions at Fram Strait. 


\subsection{Origins of the exported waters.}

Proshutinsky et al. (2002) suggested that the Beaufort Gyre could accumulate an important part of the freshwater content anomaly. The variability of the Sea Surface Height (SSH) anomaly in the Beaufort Gyre would thus be linked with the ocean freshwater export from the Arctic Ocean. Steele et al. (1996) and Thomas et al. (1996) also suggest that the Beaufort Gyre has a major role in the Arctic freshwater balance. They distinguish between the Bering Strait ocean freshwater input and the runoff that would be stored on the Siberian side of the Beaufort Gyre, and the sea-ice component mostly visible in the Canadian edge of the gyre. Could the contrast between the freshwater flux variability along both sides of Greenland find its origin in the way the ocean freshwater is stored in the Arctic Ocean, especially in the Beaufort gyre?

In the model, the correlation between the Beaufort Gyre SSH variability and the times series of the freshwater flux across Fram Strait or Davis Strait remains unsignificant at every lag. Moreover, we find a significant zero-lag correlation between the freshwater flux entering through Bering Strait and the fluxes exiting into Fram Strait and Davis Strait (respectively r=-0.52, significance 95\%, n=30 and r=0.40, significance 95\%, $\mathrm{n}=26$ ). This seems to contradict the idea of Proshutinsky et al. (2002), who see the gyre as a 'Flywheel', where the freshwater is stored and then released trough the CAA, and Fram Strait. Our model results suggest that any storage and release happens in less than one year. A complete study of the Arctic Ocean dynamics and the characteristic time scales of the circulation remains beyond the scope of the present paper.

We now investigate why the waters exported through Davis Strait into the Labrador Sea have almost constant salinity, while it varies on the eastern side of Greenland. Fig. 14 shows the time-correlations between the ocean-ice flux variability and the variability of the freshwater flux trough Fram Strait. As the sea-ice melts, salinity in the upper layer of the ocean decreases and thus the freshwater export through Fram Strait 
increases. The area where the correlations are the strongest is also the one where the variability of the ocean-ice flux is highly correlated with the variability of the salinity in the 500 upper meters of the ocean (not shown). Moreover, the sea-ice drift pattern also shows that the most important part of the exported sea-ice through Fram Strait have get passed through this area in the North of Greenland. Salinity of waters exported through Fram Strait is then strongly dependent of their interactions with sea-ice exported by the same pathway and the way it melts on surface, while waters exiting through Davis Strait are less influenced by this and their salinity is roughly constant.

\section{Conclusions.}

Direct observations of the Arctic Ocean hydrographic properties and circulation are still limited and insufficient to understand the mechanisms responsible for their variability. Here we have used a global ocean/sea-ice coupled model to investigate the freshwater budget of the Arctic Ocean and analyze the variations of its different components. A validation of the hindcast simulation has been done, examining the mean state of the Arctic Ocean proprieties and circulation, and comparing the mean freshwater budget over the 1965-2002 period, with previous estimates from direct observations of the various sources and sinks. As the model reproduces the already observed components of the Arctic freshwater and mass budgets with reasonable accuracy, we focus on the interannual variability of the different components. A limitation of our model however is the fact that the interannual variability in river runoff and precipitation is excluded.

Sea-ice and ocean freshwater advective contributions have been quantified across the four sections enclosing our domain: Bering Strait, Davis Strait, Fram Strait and a section across the Barents Sea. The mean circulation across these four transects is reproduced remarkably well, thanks to the fine model resolution. The freshwater inflow through Bering Strait is the only source that drives an important part of the simulated Arctic freshwater content variability. Ocean and sea-ice freshwater transports at Fram Strait have 
similar magnitudes.

A special interest has been given to the Arctic freshwater exports along both sides of Greenland, where time varying volume fluxes are highly anti-correlated. The net ocean freshwater flux variability is controlled by the variability of the freshwater export through Fram and Davis Straits. Freshwater flux variations are controlled by velocity variations at Davis Strait, and by both salinity and velocity variations across Fram Strait.

Our study provides a synthesis of the freshwater storage and export of the Arctic Ocean. Liquid freshwater enters the Arctic through Bering Strait, runoffs and precipitation. As the liquid freshwater flux entering through Bering Strait is only partly correlated with the total freshwater flux exiting into the North Atlantic $(r=0.44$, significance $95 \%, n=27)$, it seems that the waters are modified while they cross the Arctic Ocean. It is clearly the case for the waters exported through Fram Strait. Their salinity is strongly influenced by the melt and the formation of sea-ice along the northern side of Greenland. The role of the Beaufort Gyre does not appear clearly in the present study, but this was also noted by Häkkinen and Proshutinsky (2004) in a coarser resolution model. A more detailed analysis of the dynamics of the Arctic Ocean and the time scales associated with freshwater storage will be the subject of a forthcoming paper. 


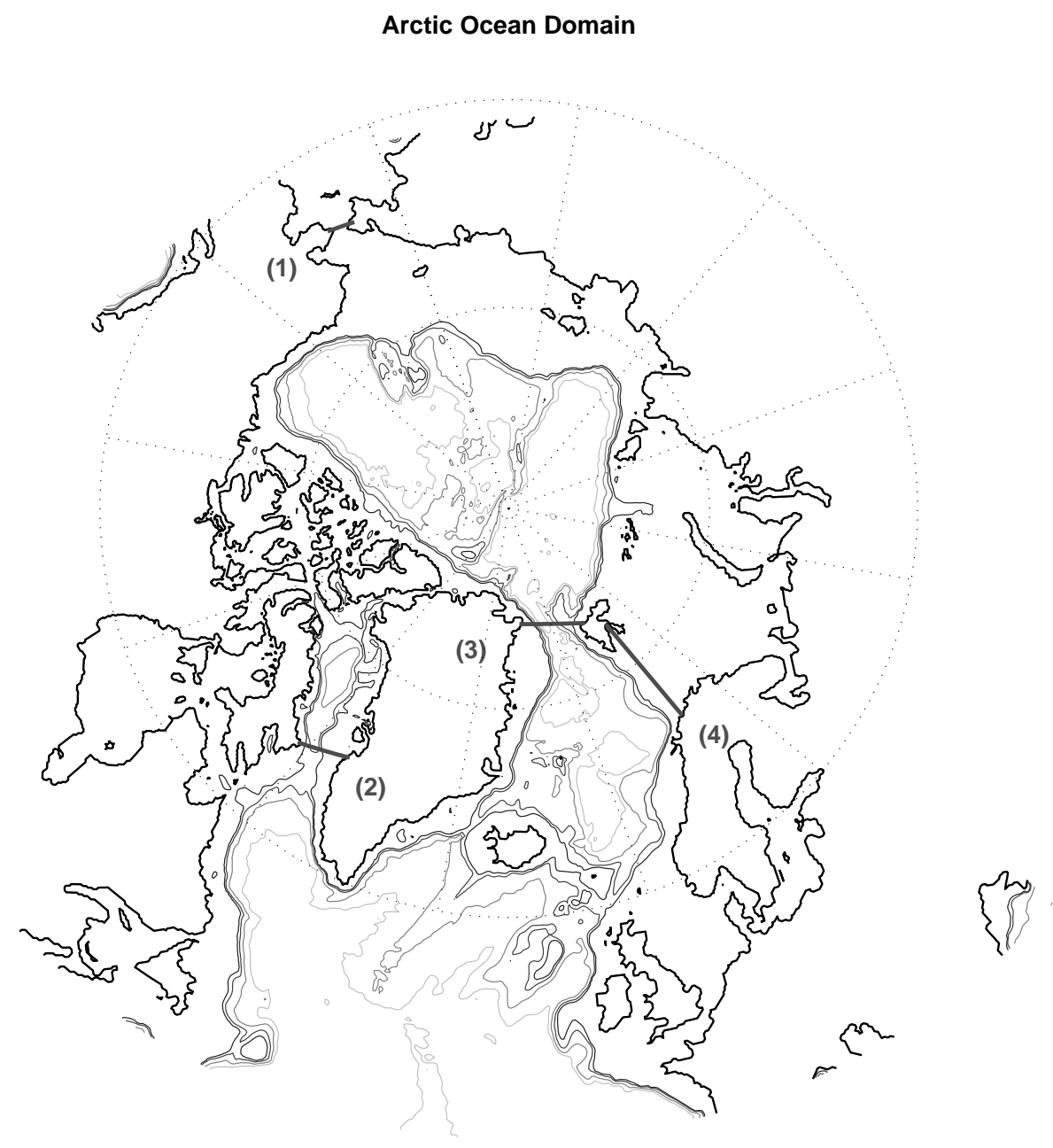

Fig. 1. Map showing the bathymetry (in meters as a unit) of the Arctic Ocean. The domain is enclosed by four sections: the Bering Strait (1), the Davis Strait (2), the Fram Strait (3), and the Barents Section (4). The isobaths shown are 500, 1000, 2000, 3000, 4000 and $5000 \mathrm{~m}$. 

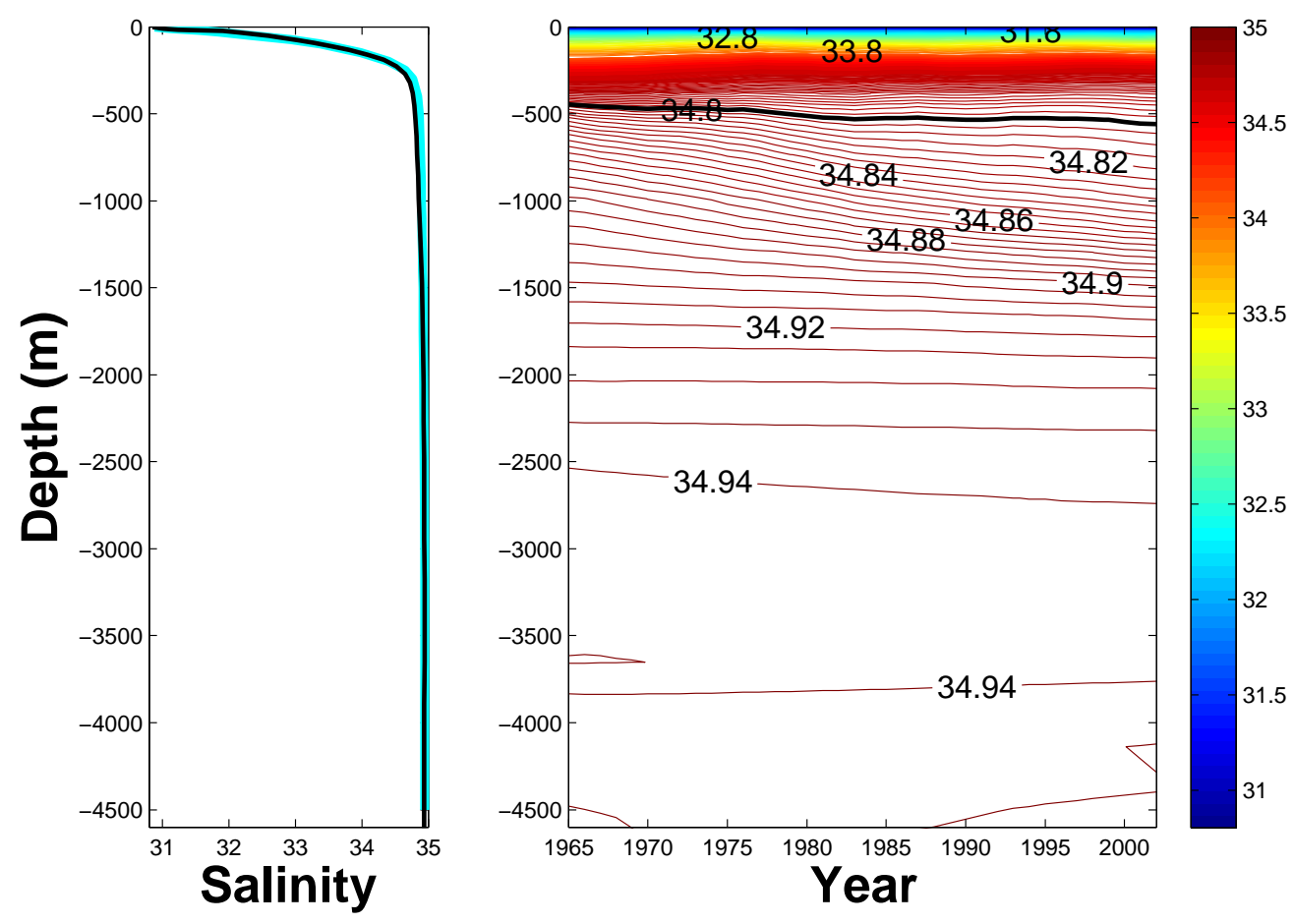

Fig. 2. Left: Annual average salinity profile (in psu) for the 1965-2002 period over the Arctic domain (see text for domain definition). The simulated salinity profile (thin black line) and the PHC climatology salinity profile (cyan line) are indicated. Right: Time-Depth section of annual mean salinity profile (in psu) over the Arctic domain. 


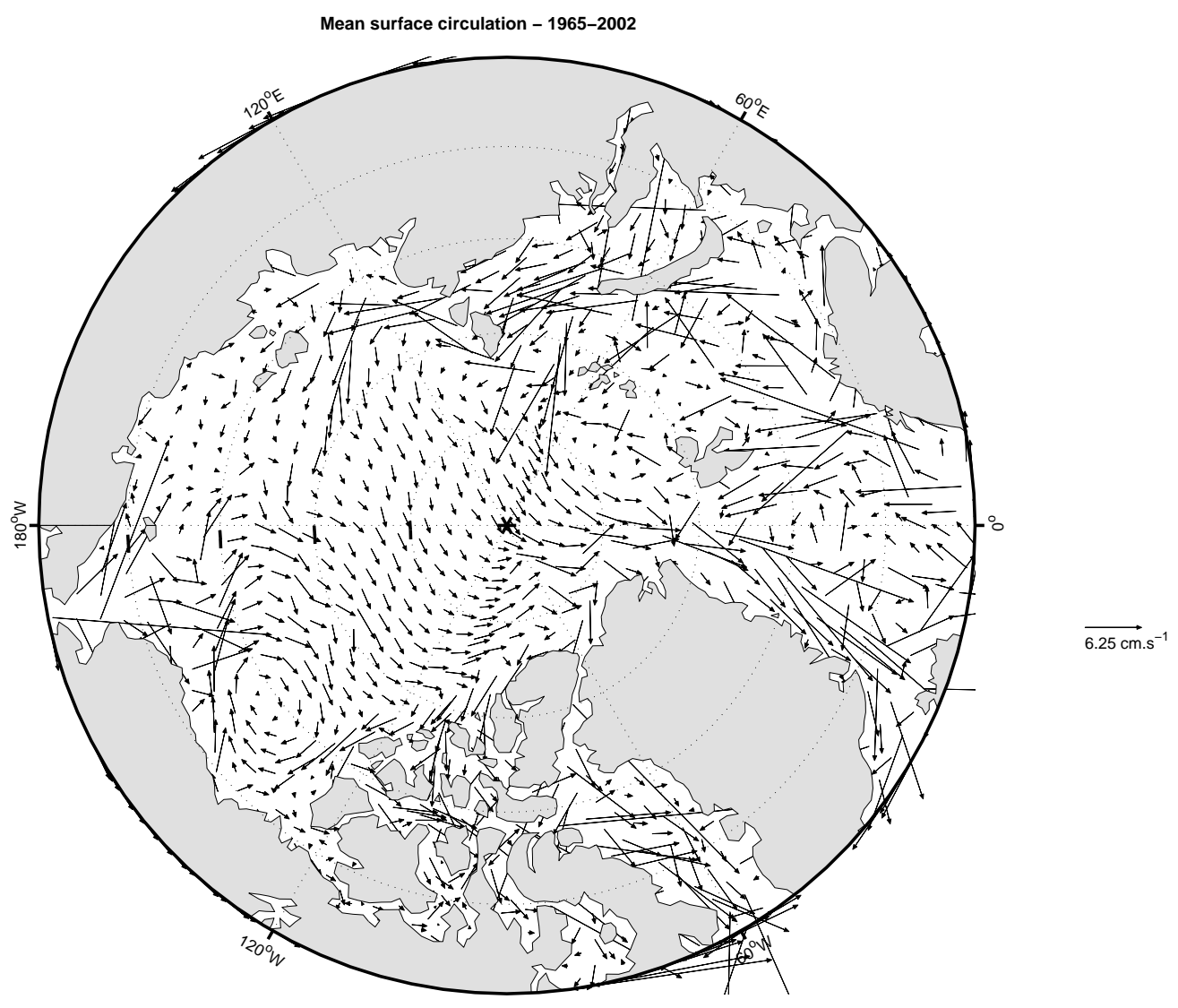

Fig. 3. The annual averaged surface circulation over the Arctic Ocean for the EXP1. 


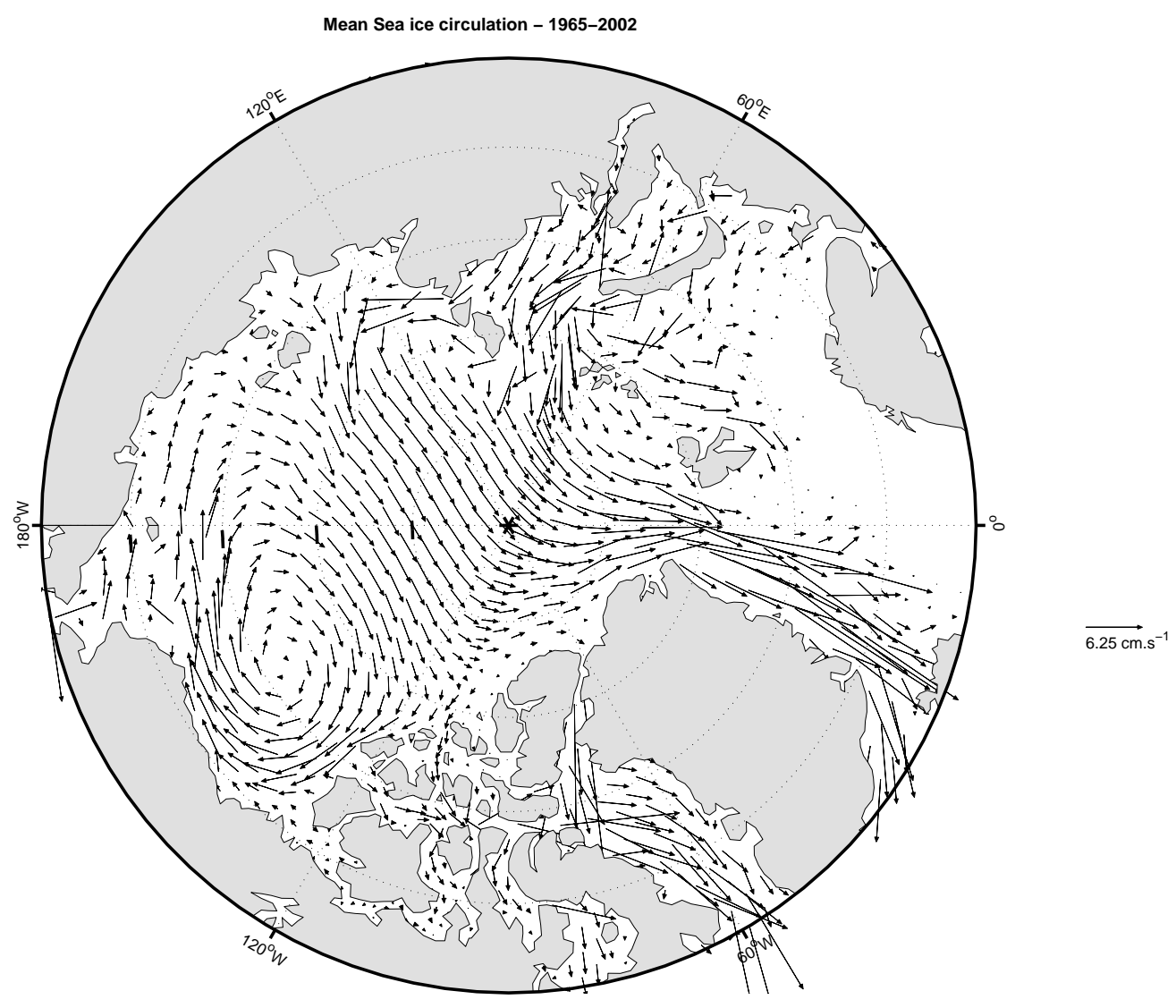

Fig. 4. The annual averaged sea-ice velocity over the Arctic Ocean for the EXP1. 


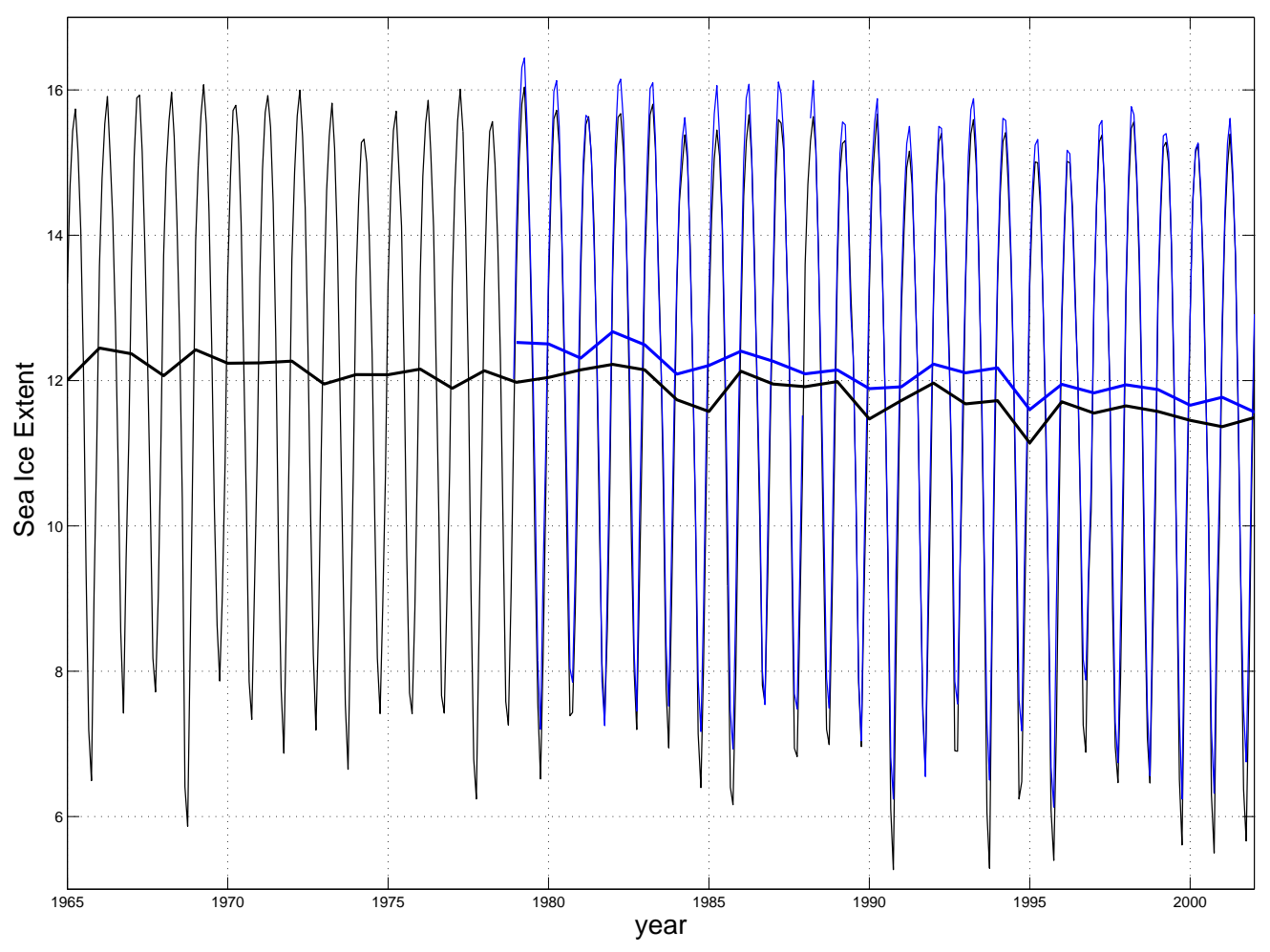

Fig. 5. Time series of the Arctic sea-ice extent monthly (thin line) and annual (thick line) mean $\left(\times 10^{6} \mathrm{~km}^{2}\right)$ from EXP1 (black line) and observations (blue line). See text for definition of the domain considered and data description. 


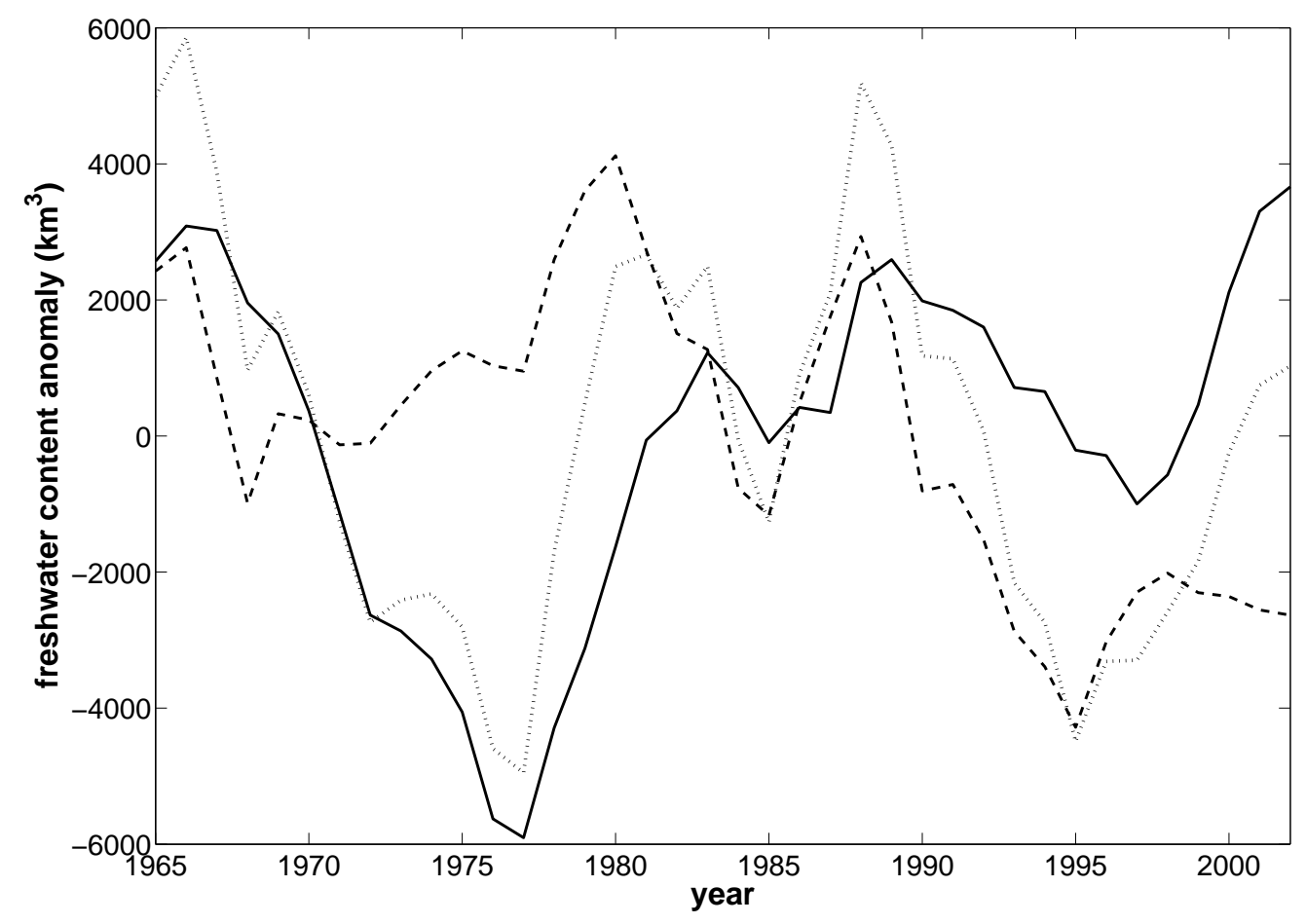

Fig. 6. Time series of Arctic Ocean freshwater content anomaly. Reference salinity is 34.8 psu. The liquid freshwater anomaly (solid lines), the sea-ice anomaly (dashed lines) and the total freshwater anomaly (dotted lines) are indicated. 

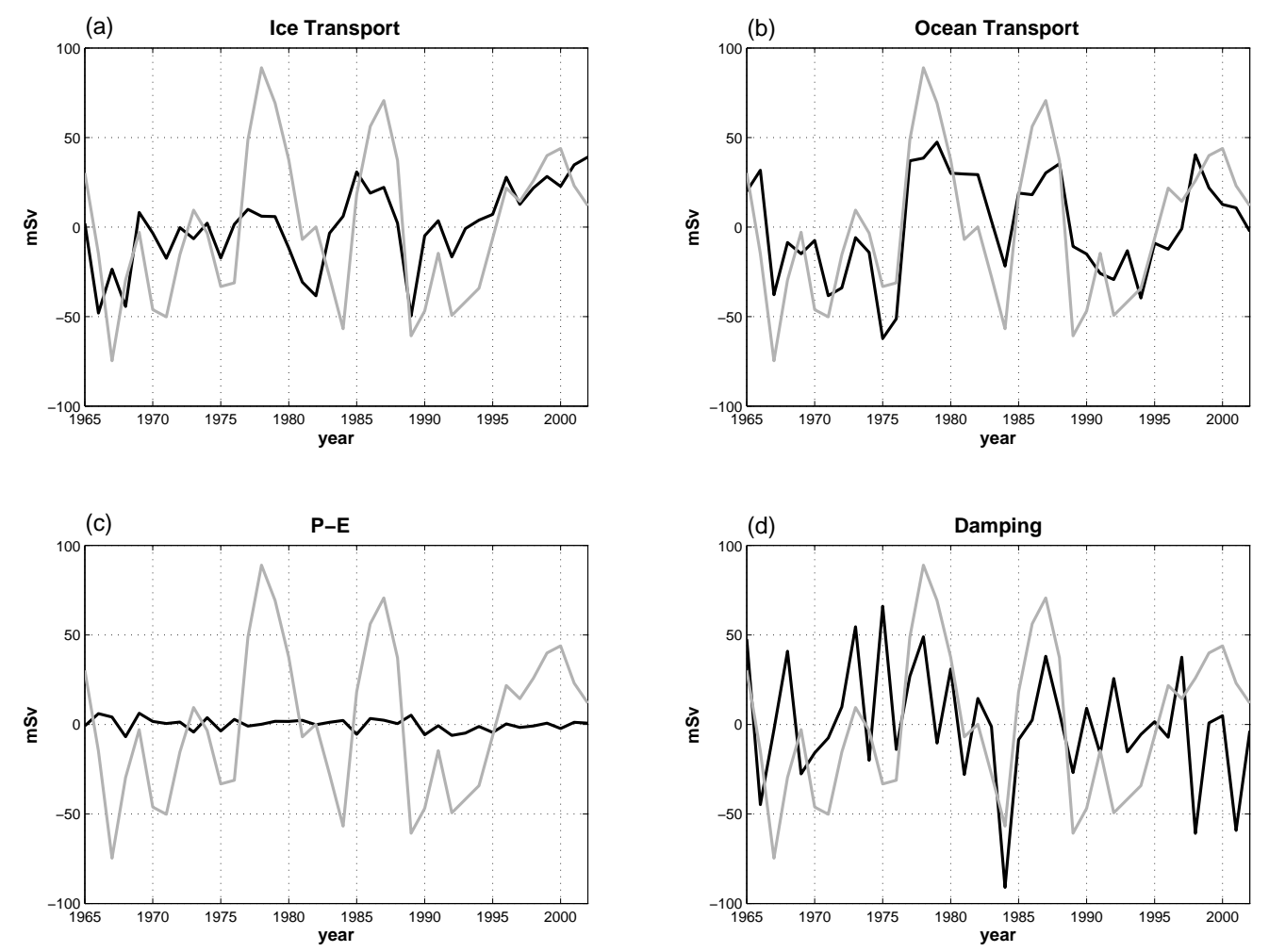

Fig. 7. Time series of the anomalies of: (a) sea-ice transport, (b) ocean transport, (c) net precipitation , and (d) damping over the period 1965-2002 for the EXP1 run. The time series of the anomalies of the freshwater content derivative is also stacked on each plot (gray line). 


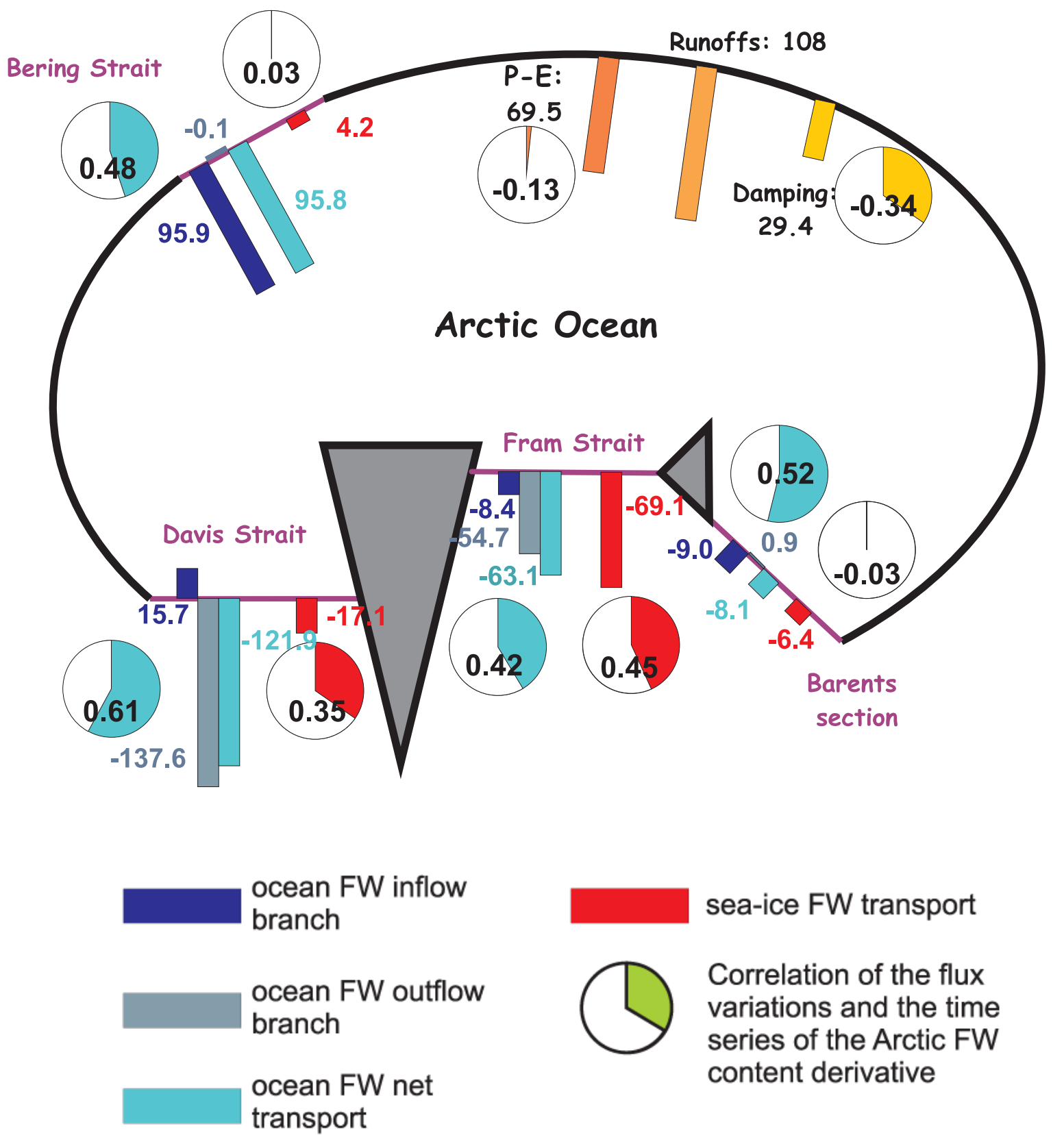

Fig. 8. Schematic view of the Arctic freshwater balance. Mean value of each source and sink is represented (bar, in $\mathrm{mSv}$ ), as well as the correlation of its variations with the times series of the Arctic freshwater content derivative (circular diagrams). The sign of the freshwater fluxes indicates if the flux represents a sink or a source of freshwater for the Arctic Ocean, regardless the direction of the volume fluxes (For instance, the inflow branch through Fram Strait brings waters with salinity higher than 34.8 , and thus has a negative sign). 

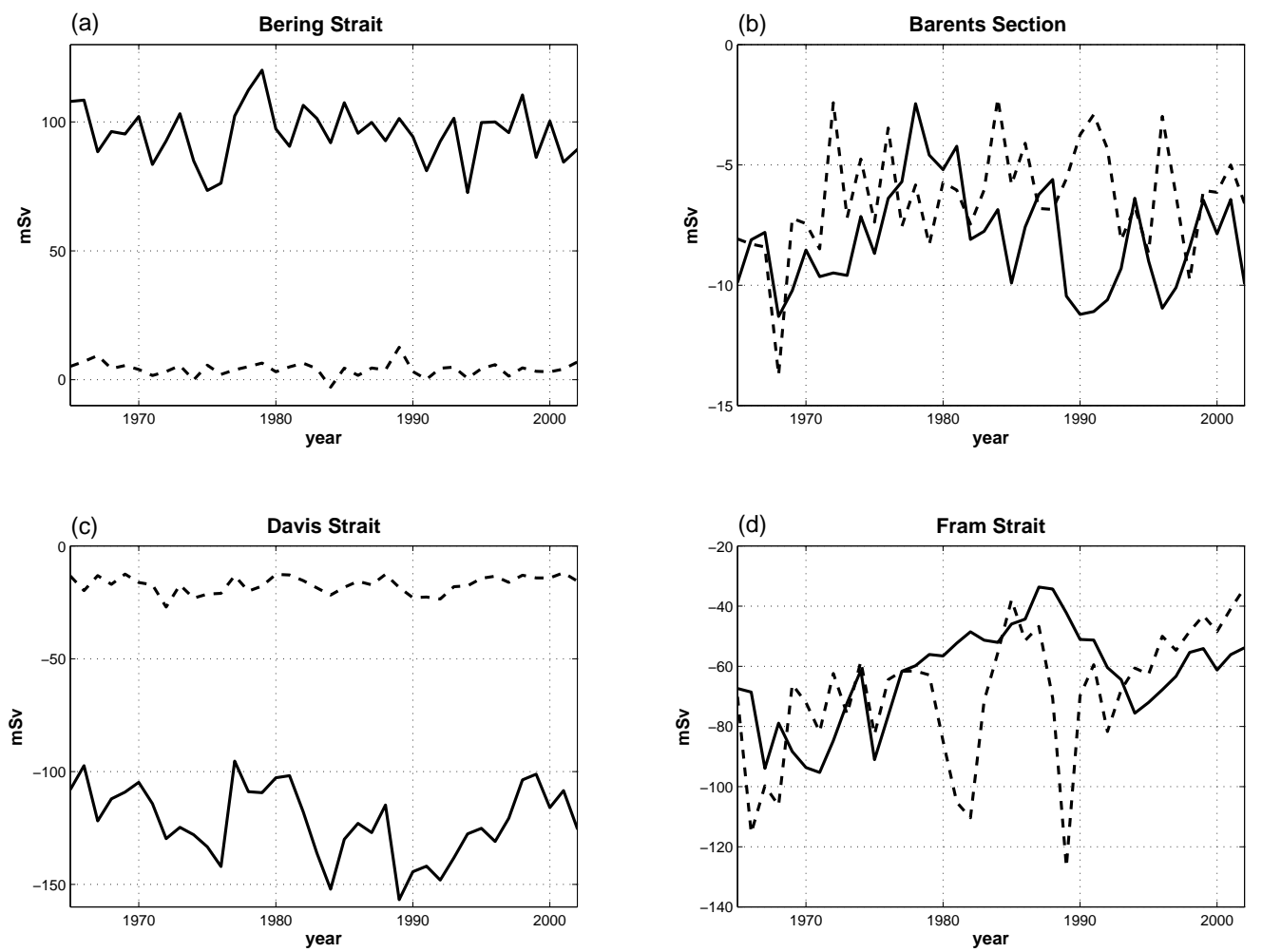

Fig. 9. Times series of the ocean freshwater transport (solid line) and sea-ice freshwater transport (dashed line) through (a) Bering Strait, (b) Barents section, (c) Davis Strait, and (d) Fram Strait. The reference salinity is 34.8 psu. The sign convention is such that a source of freshwater for the Arctic Ocean is a positive value. 

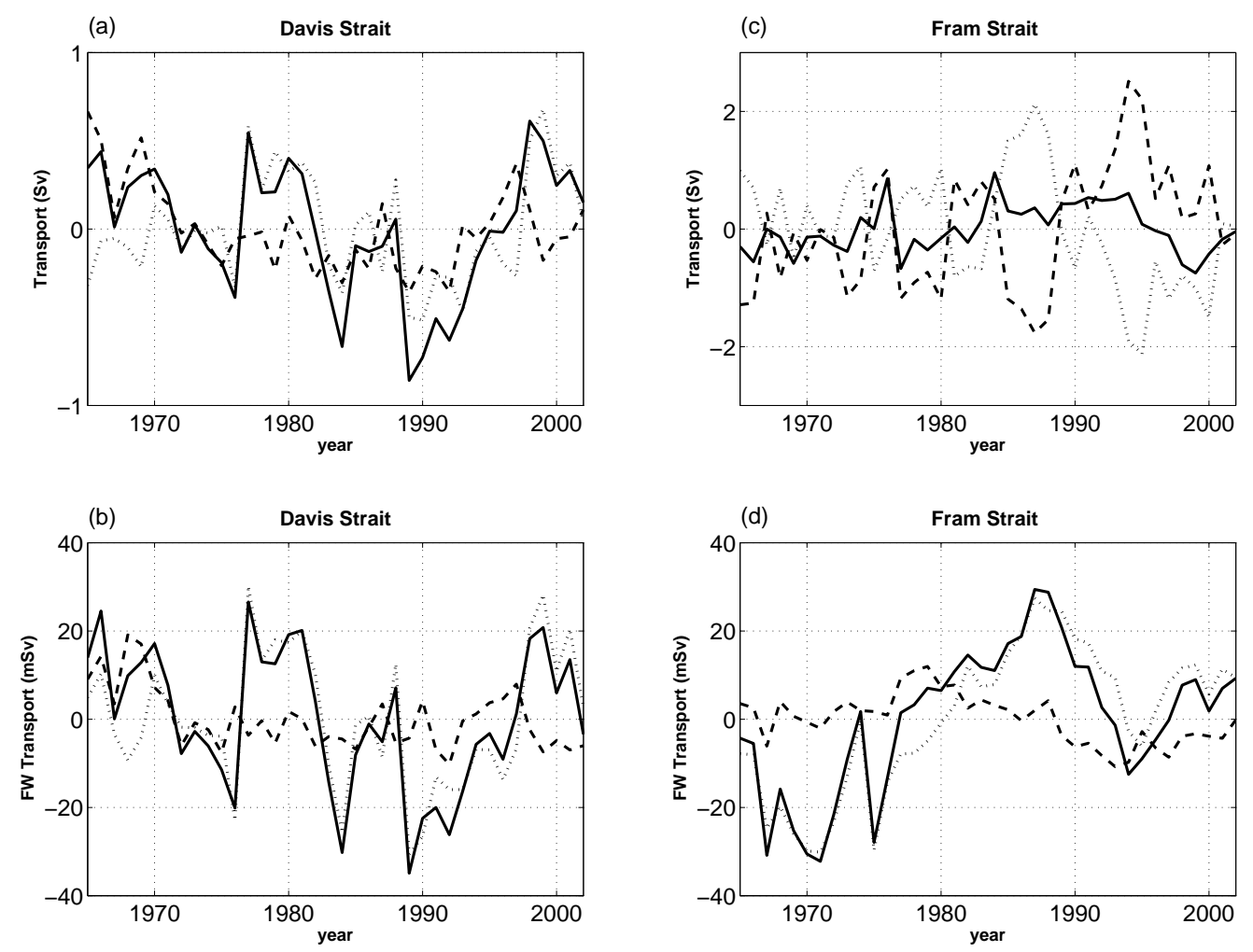

Fig. 10. Times series of the volume transport anomalies ((a) and (c)) and the liquid freshwater transport anomalies ((b) and (d)) across Davis Strait and Fram Strait. The net fluxes (solid lines), the northward fluxes (dashed lines) and the southward fluxes (dotted lines) are indicated. Mean values are given in Table 3. 

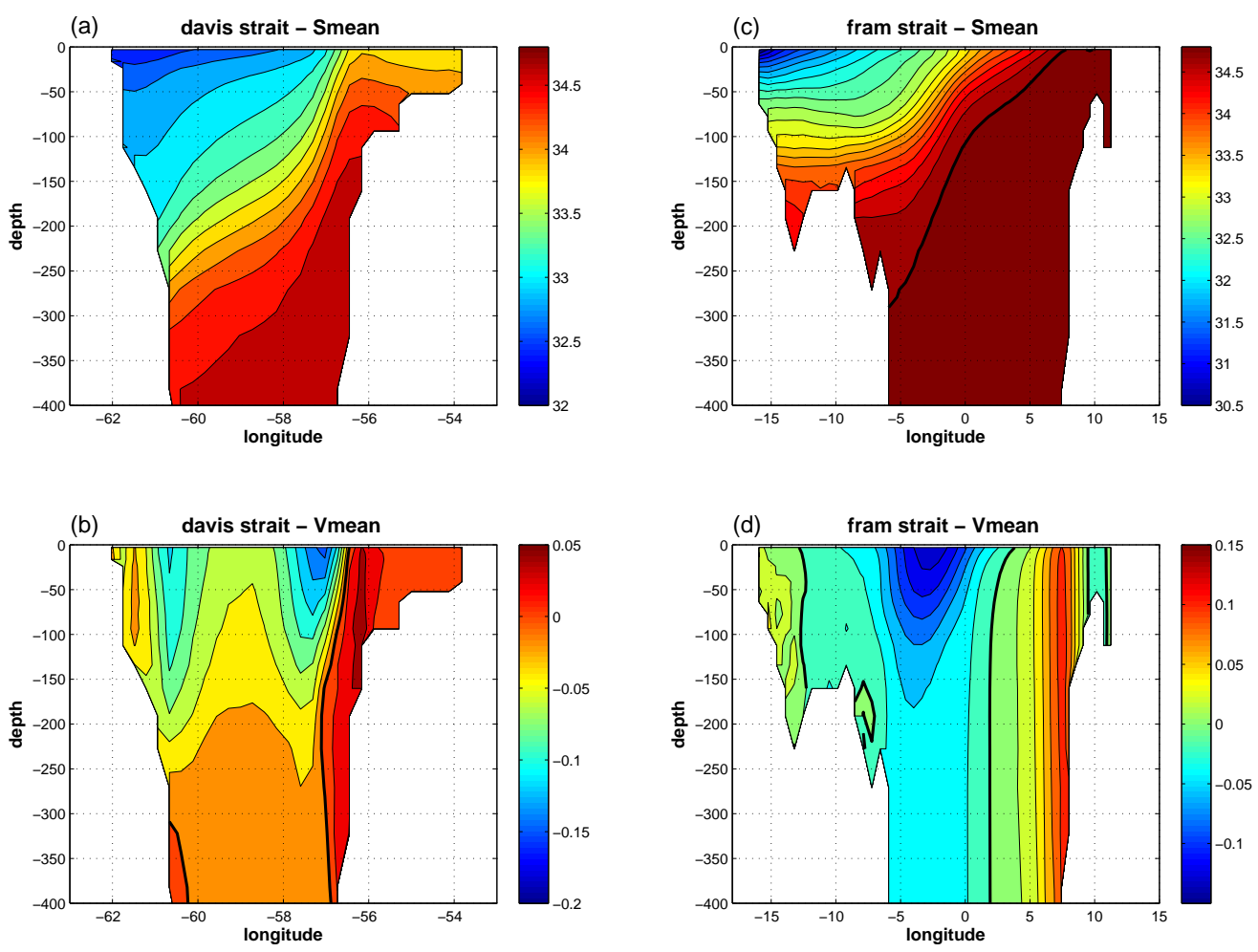

Fig. 11. Section of mean salinity (in psu) and speed (in $\mathrm{m} / \mathrm{s}$ ) of the 400 upper meters across Davis Strait (a and b) and across Fram Strait (c and d). Calculations are done over the 1965-2002 period for the EXP1 run. The 34.8 isohaline and the null speed contour are indicated in bold. We just represent the upper part of the two sections where the transport and the freshwater transport have significant contributions. 

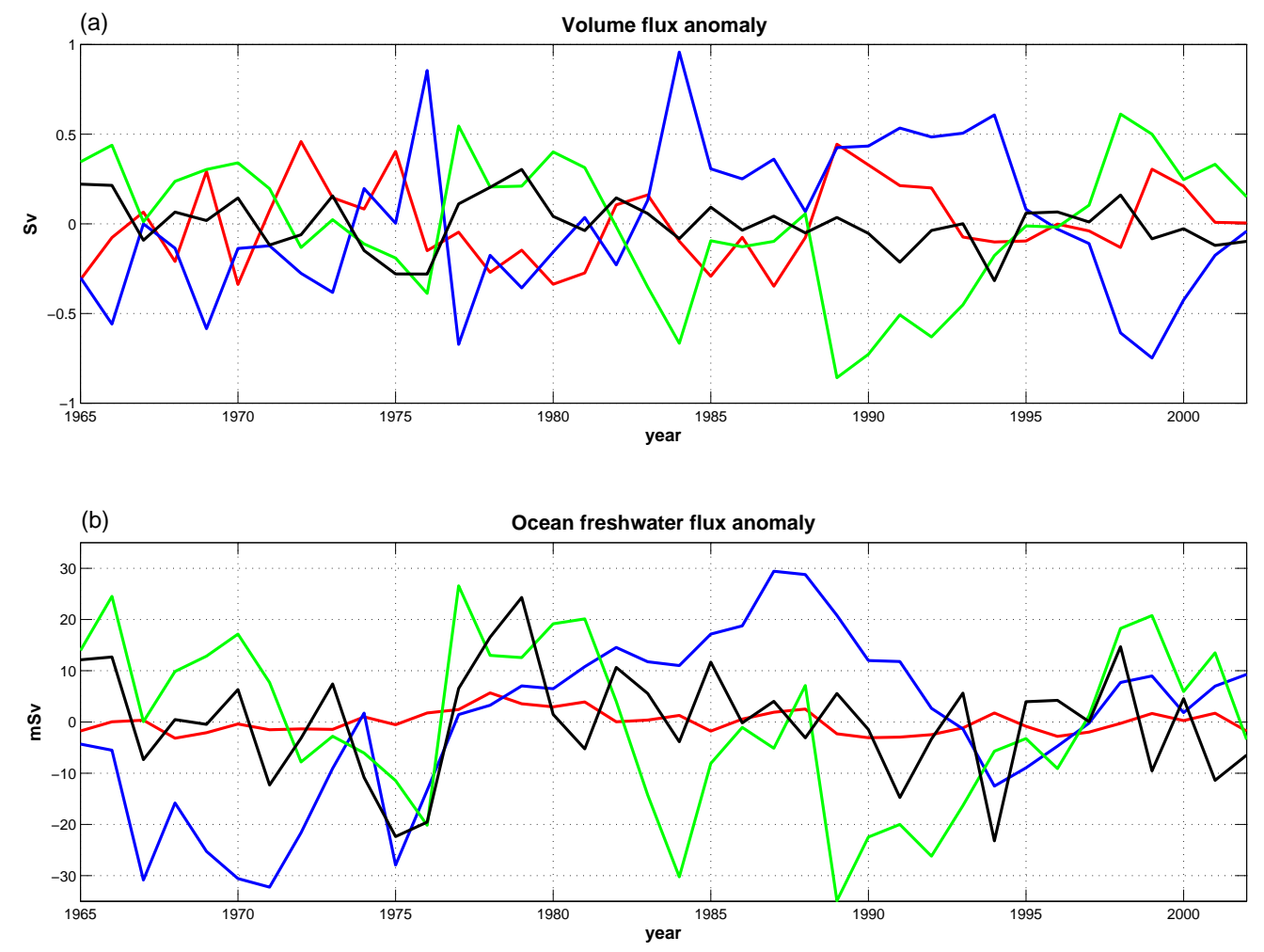

Fig. 12. Anomaly of the volume flux (a) and the freshwater flux (b) across the four sections enclosing the Arctic Basin: the Barents section is plotted in red, Fram Strait in blue, Davis Strait in green and Bering Strait in black. 

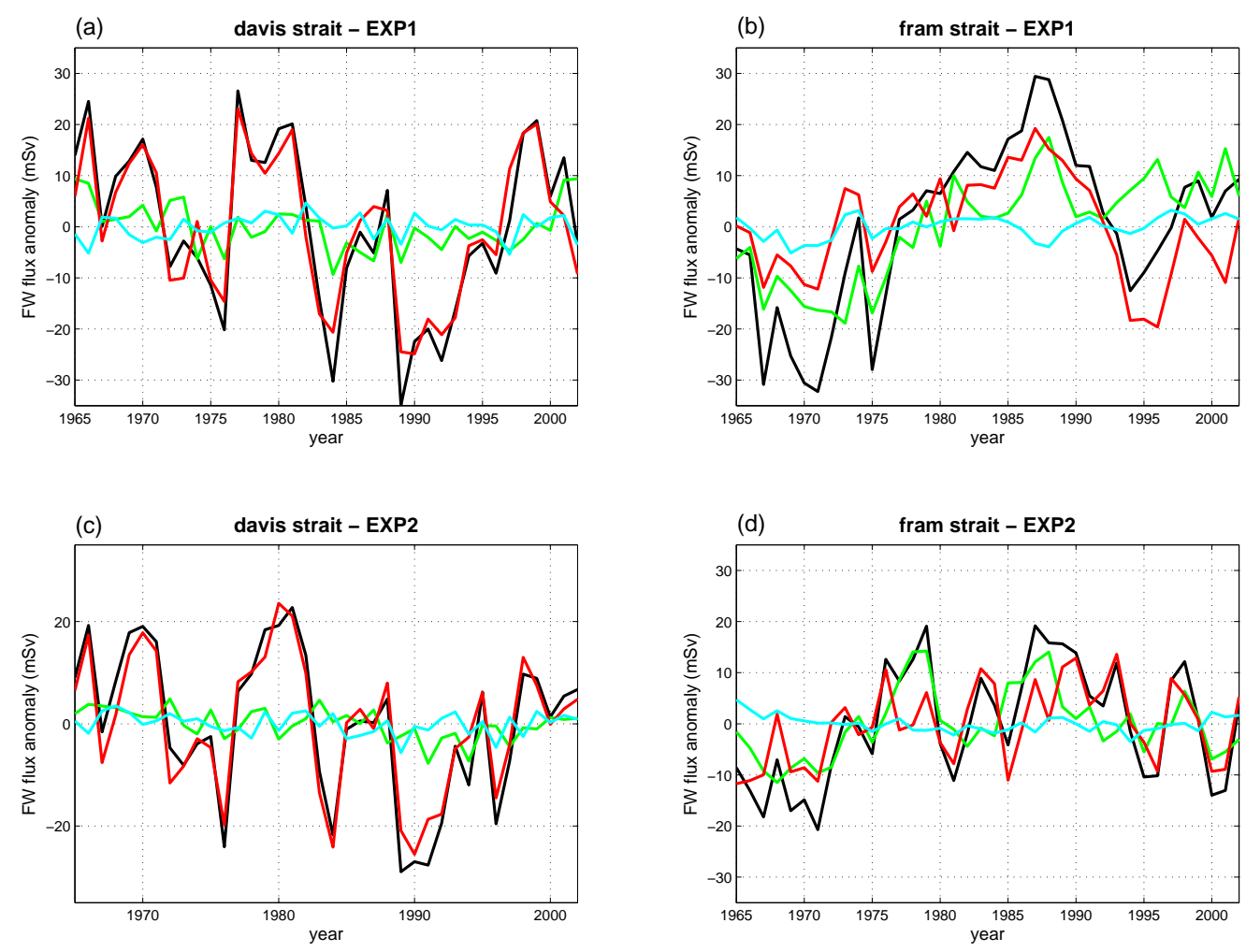

Fig. 13. Analysis of the ocean freshwater transport across Davis Strait (a and c) and Fram Strait (b and d) for the two runs (EXP1 for a and b, and EXP2 for $\mathrm{c}$ and d). Time Series of the four terms anomalies of the analysis are shown: $T_{F W}\left(v, S_{1}\right)$ in black, $T_{F W}\left(v^{\prime}, S_{1}^{\prime}\right)$ in cyan, $T_{F W}\left(\bar{v}, S_{1}^{\prime}\right)$ in green and $T_{F W}\left(v^{\prime}, \bar{S}_{1}\right)$ in red. 


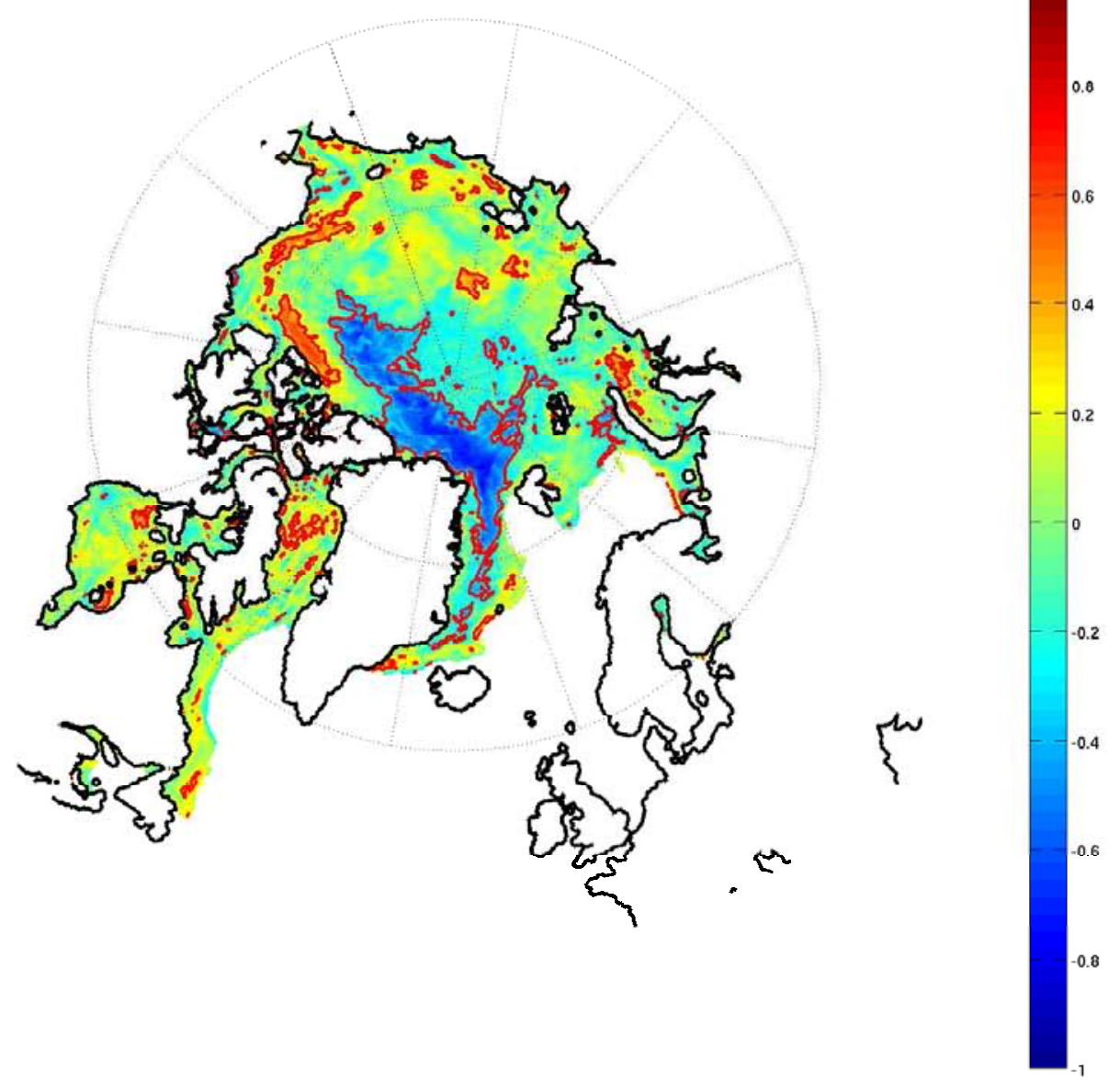

Fig. 14. Correlation between the ocean freshwater flux through Fram Strait and the ocean-ice flux over the Arctic domain. Calculations are done over the 1965-2002 period for the EXP1 run. The 95\% significance level is indicated in red (based upon 36 degrees of freedom, which is an upper limit). 
Table 1. Average Arctic Ocean freshwater budget over the period 1965-2002. Means are calculated from monthly output. Standard deviations are calculated from annual means. Previous estimates of the means are also shown. The sign convention is such that a source of freshwater into the Arctic Ocean is a positive value. A\&C89 refer to Aagaard and Carmack (1989). Note that the sum of the budget terms, $21 \mathrm{mSv}$, is larger than the freshwater content change between january 1965 and december 2002, due to inaccuracies of the budget terms and the contribution of isopycnal diffusion, which is not taken into account. The freshwater content change is $-2.9 \mathrm{mSv}$, resulting from salinity change (-1.8 $\mathrm{mSv})$, sea surface height increase $(3.5 \mathrm{mSv})$ and sea ice volume change $(-4.6 \mathrm{mSv})$.

\begin{tabular}{lccc}
\hline Budget Term & Mean & Std & Previous Estimates and References \\
$\begin{array}{l}S_{\text {ref }}=34.8 p s u \\
(\mathrm{mSv})\end{array}$ & & Dev & \\
\hline P-E & & & \\
\hline Runoffs & $\mathbf{6 9 . 5}$ & 3.4 & 65: Serreze et al. (2006) - 31: A\&C89 \\
\hline Damping & $\mathbf{1 0 8}$ & - & 94: Lammers et al. $(2001)-102:$ Serreze et al. $(2006)$ \\
\hline
\end{tabular}

\section{Ocean Transport}

$\begin{array}{lccc}\text { Bering Strait } & 95.8 & 10.7 & \text { 79: Woodgate and Aagaard (2005) - 57: A\&C89 } \\ \text { Davis Strait } & -121.9 & 15.9 & \text {-92: Cuny et al. (2005) - 57: Loder et al. (1998) } \\ \text { Fram Strait } & -63.1 & 16.4 & -63 /-95: \text { Meredith et al. (2001) - -28: A\&C89 } \\ \text { Barents Section } & -8.1 & 2.2 & -9.6 \text { : Maslowski et al. (2004) - -18: A\&C89 } \\ \text { TOTAL } & \mathbf{- 9 7 . 4} & 28.4 & \end{array}$

\section{Ice Transport}

$\begin{array}{lccc}\text { Bering Strait } & 4.2 & 2.7 & \text { 3: Woodgate and Aagaard (2005) } \\ \text { Davis Strait } & -17.1 & 3.8 & -12.9 \text { : Cuny et al. (2005) } \\ \text { Fram Strait } & -69.1 & 22.2 & -56: \text { Kwok and Rothrock (1999) - -88: Dickson et al. (2007) } \\ \text { Barents Section } & -6.4 & 2.3 & -3.9: \text { Kwok et al. (2005b) } \\ \text { TOTAL } & \mathbf{- 8 8 . 4} & 22.3 & \end{array}$


Table 2. Liquid and Ice freshwater content. Mean value, standard deviation and linear trend are calculated for each component for the 1965-2002 period. Means are calculated from monthly output. Standard deviations and linear trends are calculated from annual mean.

\begin{tabular}{lccc} 
Freshwater Content & Mean $\left(\mathbf{k m}^{3}\right)$ & Std Dev $\left(\mathbf{k m}^{3}\right)$ & Trend $\left(\mathbf{k m}^{3} / \mathbf{d e c a d e}\right)$ \\
\hline Liquid & $5.86 .10^{4}$ & 2480 & 15.4 \\
Ice & $1.50 .10^{4}$ & 2140 & -31.6 \\
Total & $7.46 .10^{4}$ & 2840 & -16.2 \\
\hline
\end{tabular}


Table 3. Averages of the volume, ocean freshwater and sea-ice exchanges across the four transects enclosing the Arctic Basin (see text for definition of the domain). Means are calculated from monthly output. The sign convention is such that a source of freshwater for the Arctic Ocean is a positive value.

\begin{tabular}{|c|c|c|c|c|c|}
\hline & & Bering Strait & Barents Section & Davis Strait & Fram Strait \\
\hline \multirow[b]{2}{*}{ Transport } & inflow & 1.3 & 4.1 & 1.2 & 6.5 \\
\hline & outflow & 0 & -1.2 & -3.7 & -8.3 \\
\hline (Sv) & net & 1.3 & 2.9 & -2.5 & -1.8 \\
\hline Ocean FW & inflow & 95.9 & -9.0 & 15.7 & -8.4 \\
\hline Transport & outflow & -0.1 & 0.9 & -137.6 & -54.7 \\
\hline$(\mathrm{mSv})$ & net & 95.8 & -8.1 & -121.9 & -63.1 \\
\hline \multicolumn{6}{|l|}{ Sea-ice FW } \\
\hline $\begin{array}{c}\text { Transport } \\
(\mathbf{m S v})\end{array}$ & net & 4.2 & -6.4 & -17.1 & -69.1 \\
\hline
\end{tabular}


Table 4. Correlations between the time series of the ocean freshwater and sea-ice exchanges across the four transects enclosing the Arctic Basin and the time series of the freshwater content derivative. Effective degrees of freedom (n) and statistical significance level are indicated (in brackets) for correlation coefficients that are significant (shown in bold font). Only significant correlations are referred to in the text.

\section{Ocean freshwater transport Sea-ice freshwater transport}

\begin{tabular}{ccc}
\hline Bering Strait & $\mathbf{0 . 4 8}(\mathrm{n}=29,95 \%)$ & 0.03 \\
Barents Section & $\mathbf{0 . 5 2}(\mathrm{n}=18,95 \%)$ & -0.03 \\
Davis Strait & $\mathbf{0 . 6 1}(\mathrm{n}=20,95 \%)$ & $\mathbf{0 . 3 5}(\mathrm{n}=27,90 \%)$ \\
Fram Strait & $\mathbf{0 . 4 2}(\mathrm{n}=15,90 \%)$ & $\mathbf{0 . 4 5}(\mathrm{n}=21,95 \%)$ \\
\hline
\end{tabular}


Table 5. Mean, Standard deviation (std) and correlation (r) with the ocean freshwater flux of each contribution to the transport as defined by Eq. 1 across Davis Strait and Fram Strait, for the two experiments (EXP1 and EXP2). Means are calculated from monthly output. Standard deviations are calculated from annual mean. For the correlation coefficients, bold font indicates statistical significance at $95 \%$ confidence level or higher and effective degrees of freedom (n) are indicated in bracket. Only significant correlations are referred to in the text.

\begin{tabular}{|c|c|c|c|c|c|}
\hline & & \multicolumn{2}{|c|}{ DAVIS STRAIT } & \multicolumn{2}{|c|}{ FRAM STRAIT } \\
\hline & & EXP1 & $E X P 2$ & EXP1 & $E X P 2$ \\
\hline \multirow[b]{2}{*}{$T_{F W}\left(v, S_{1}\right)$} & Mean (mSv) & -121.9 & -61.2 & -62.4 & -33.8 \\
\hline & $S t d(m S v)$ & 15.9 & 14.6 & 16.1 & 11.4 \\
\hline \multirow{3}{*}{$T_{F W}\left(v^{\prime}, S_{1}^{\prime}\right)$} & Mean $(m S v)$ & -10.4 & -6.2 & -1.4 & -1.9 \\
\hline & $S t d(m S v)$ & 2.3 & 2.1 & 2.1 & 1.6 \\
\hline & $r$ & 0.09 & 0.30 & 0.25 & -0.17 \\
\hline \multirow{3}{*}{$T_{F W}\left(\bar{v}, S_{1}^{\prime}\right)$} & Mean $(m S v)$ & 0 & 0 & 0 & 0 \\
\hline & $S t d(m S v)$ & 4.7 & 2.9 & 9.9 & 6.8 \\
\hline & $r$ & $0.52(n=23)$ & 0.34 & $\mathbf{0 . 7 0}(n=9)$ & $0.76(n=14)$ \\
\hline \multirow{3}{*}{$T_{F W}\left(v^{\prime}, \bar{S}_{1}\right)$} & Mean $(m S v)$ & 0 & 0 & 0 & 0 \\
\hline & $S t d(m S v)$ & 1.4 & 13.1 & 9.7 & 7.7 \\
\hline & $r$ & $0.95(n=15)$ & $0.97(n=17)$ & $\mathbf{0 . 8 0}(n=6)$ & $\mathbf{0 . 8 1}(\mathrm{n}=17)$ \\
\hline \multirow[b]{2}{*}{$T_{F W}\left(\bar{v}, \bar{S}_{1}\right)$} & Mean $(m S v)$ & -111.6 & -55.0 & -61.0 & -32.0 \\
\hline & $S t d(m S v)$ & 0 & 0 & 0 & 0 \\
\hline
\end{tabular}




\section{Details on the freshwater balance.}

The liquid freshwater stored in our domain is computed as:

$$
F W_{l i q}=\iiint \frac{S_{0}-S}{S_{0}} d V
$$

where $V$ is the volume of the domain, $S$ is the salinity calculated by the model, and $S_{0}$ is a reference salinity, here equal to a value of 34.8 psu (this choice will be discussed later). As we assume a constant sea-ice salinity $S_{\text {ice }}$ of $6 \mathrm{psu}$, the sea-ice freshwater content is defined as:

$$
F W_{\text {ice }}=\frac{S_{0}-S_{\text {ice }}}{S_{0}} V_{\text {ice }}
$$

where $V_{\text {ice }}$ is the sea-ice volume. The freshwater transport across a section is defined as the sum of two contributions, the ice part and the liquid part:

$$
\begin{gathered}
T_{F W}=T_{F W \text { liq }}+T_{F \text { Wice }} \\
T_{F W}=\iint U \frac{S_{0}-S}{S_{0}} d A+\int \frac{\left(S_{0}-S_{\text {ice }}\right)}{S_{0}} \times \frac{C_{\text {ice }}}{100} \times \frac{\rho_{\text {ice }}}{\rho_{\text {water }}} \times U_{\text {ice }} \times d h
\end{gathered}
$$

with $U$ being the speed across the section of area $A, U_{\text {ice }}$ the ice velocity, $h$ the ice thickness, $C_{i c e}$ the sea-ice concentration, $\rho_{\text {ice }}$ the sea-ice density $\left(900 \mathrm{~kg} \cdot \mathrm{m}^{-3}\right)$ and $\rho_{\text {water }}$ the density of water $\left(1000 \mathrm{~kg} \cdot \mathrm{m}^{-3}\right)$.

The freshwater balance of the area can be expressed as follows:

$$
\begin{aligned}
F W(t)=\int \delta t\left\{T_{F W}(\text { Bering })+T_{F W}(\text { Barents })+\right. & \left.T_{F W}(\text { Fram })+T_{F W}(\text { Davis })\right\} \\
& +\int \delta t\{(E-P-R)+D P\}
\end{aligned}
$$

with $E-P$ representing the surface evaporation rate minus the precipitation rate over the whole surface of the domain, $R$ being the runoff and $D P$ being the surface damping. 
The definition of the freshwater fluxes and contents are strongly dependent on a reference salinity, $S_{0}$. For this study, we choose 34.8 psu as the reference salinity, mostly as to follow Aagaard and Carmack (1989). This salinity is considered as being a reasonable estimate of the mean Arctic salinity and is the most commonly adopted in the literature. In this way, when we will consider the exchanges between the Arctic Ocean and the subpolar area, the sign of the freshwater fluxes will indicate if the flux represents a sink or a source of freshwater for the Arctic Ocean, regardless the direction of the volume fluxes. 
Acknowledgements. This study uses numerical experiments carried out within the DRAKKAR project. EXP1 has been run at the IDRIS CNRS computer centre in Orsay, France, by J.M. Molines. The integration of the experiment EXP2 has been performed at the Höchstleistungsrechenzentrum Stuttgart (HLRS) by A. Biastoch. C. Lique is supported by CNES and IFREMER. A.M. Treguier and T. Penduff are supported by CNRS. The model integration and the analysis by M. Scheinert was supported by the BMBF Nordatlantik project 03F0443B AP3.2. We also thank C. Herbaut and M.N. Houssais for useful discussions. 


\section{References}

Aagaard, K., Carmack, E., 1989. The role of sea ice and other fresh water in the arctic circulation. Journal of Geophysical Research 94, 14,485-14,498.

Barnier, B., Madec, G., Penduff, T., Molines, J. M., Treguier, A. M., Sommer, J. L., Beckmann, A., Biastoch, A., Boning, C., Dengg, J., Derval, C., Durand, E., Gulev, S., Remy, E., Talandier, C., Theetten, S., Maltrud, M., McClean, J., Cuevas, B. D., 2006. Impact of partial steps and momentum advection schemes in a global ocean circulation model at eddy permitting resolution. Ocean Dynamics 56, 543-567.

Brodeau, L., Barnier, B., Penduff, T., Treguier, A. M., Gulev, S., 2008. An evaluation of era-40 and core atmospheric variables as drivers of global ocean models. Submitted to Ocean Modelling .

Cavalieri, D. J., Parkinson, C. L., Vinnikov, K. Y., 2003. 30-year satellite record reveals contrasting arctic and antarctic decadal sea ice variability. Geophysical Research Letters 30(18).

Cuny, J., Rhines, P. B., Kwok, R., 2005. Davis strait volume, freshwater and heat fluxes. Deep-sea research, Part 1 $52,519-542$.

Dai, A., Trenberth, K., 2002. Estimates of freshwater discharge from continents: latitudinal and seasonal variations. Journal of hydrometeorology 3, 660-687.

DeBoer, A. M., Nof, D., 2004. The exhaust valve of the north atlantic. Journal of Climate 17(3), 417-422.

Dickson, R., Rudels, B., Dye, S., Karcher, M., Meinck, J., Yashayaev, I., 2007. Current estimates of freshwater flux through arctic and subarctic seas. Progress in Oceanography 73, 210-230.

Dickson, R. R., Osborn, T. J., Hurrell, J. W., Meincke, J., Blindheim, J., Adlandsvik, B., Vinje, T., Alekseev, G., Maslowski, W., 2000. The arctic ocean response to the north atlantic oscillation. Journal of Climate 13(15), 26712696.

Fahrbach, E., Meincke, J., Osterhus, S., Rohardt, G., Schauer, U., Tverberg, V., Verduin, J., 2001. Direct measurements of volume transports through fram strait. Polar Research 20(2), 217-224.

Fetterer, F., Knowles, K., 2002, updated 2004. Sea ice index. 
Fichefet, T., Goosse, H., Maqueda, M. A. M., 2003. A hindcast simulation of arctic and antarctic sea ice variability, 1955-2001. Polar Research 22(1), 91-98.

Gerdes, R., Karcher, M., Köberle, C., Fieg, K., 2008. Simulating the long term variability of liquid freshwater export from the arctic ocean. In: Dickson, R. R., Meincke, J., Rhines, P. (Eds.), Arctic-Subarctic Ocean Fluxes. Springer, pp. $405-425$.

Haak, H., Jungclaus, J., Mikolajewicz, U., Latif, M., 2003. Formation and propagation of great salinity anomalies. Geophysical Research Letters 30(9), 1473-1476.

Häkkinen, S., Proshutinsky, A., 2004. Freshwater content variability in the arctic ocean. Journal of Geophysical Research 73, 210-230.

Hilmer, M., Lemke, P., 2000. On the decreas of arctic sea ice volume. Geophysical Research Letters 27, 3751-3754. Holland, M., Finnis, J., Serreze, M. C., 2006. Simulated arctic ocean freshwater budgets in the twentieth and twentyfirst centuries. Journal of Climate 19, 6221-6242.

Jones, E. P., Anderson, L. G., 2008. Is the global conveyor belt threatened by arctic ocean fresh water outflow? In: Dickson, R. R., Meincke, J., Rhines, P. (Eds.), Arctic-Subarctic Ocean Fluxes. Springer, pp. 385-404.

Joyce, T. M., Proshutinsky, A., 2007. Greenland's island rule and the arctic ocean circulation. Journal of Marine Research 65, 639-653.

Köberle, C., Gerdes, R., 2003. Mechanisms determining the variability of arctic sea ice conditions and export. Journal of Climate 16, 2843-2858.

Köberle, C., Gerdes, R., 2007. Simulated variability of the arctic ocean freshwater balance 1948-2001. Journal of Physical Oceanography 37, 1628-1644.

Kwok, R., Maslowski, W., Laxon, S. W., 2005b. On large outflows of arctic sea ice into the barents sea. Geophysical Research Letters 32.

Kwok, R., Rothrock, D. A., 1999. Variability of fram ice flux and north atlantic oscillation. Journal of Geophysical Research 104, 5177-5189. 
Lammers, R. B., Shiklomanov, A. I., Vorosmarty, C. J., Fekete, B. M., Peterson, B. J., 2001. Assessment of contemporary arctic river runoff based on observational discharge records. Journal of Geophysical Research 106, 3321-3334.

Large, W., Yeager, S., 2004. Diurnal to decadal global forcing for ocean and sea-ice models: the datasets and flux climatologies. NCAR technical note NCAR/TN-460+STR, CGD division of the National Center for Atmospheric Research, available on the GFDL CORE web site.

Loder, J. W., Petrie, B., Gawarkiewicz, G. D., 1998. The coastal ocean off north-eastern north america: a large-scale view. In: The Sea, vol. 11. Wiley, New York,, pp. 105-133.

Loeng, H., Ozhigin, V., Adlandsvik, B., 1997. Water fluxes trough the barents sea. ICES Journal of Marine Science $54,310-317$.

Madec, G., Delecluse, P., Imbard, M., Levy, C., 1998. Opa 8.1 ocean general circulation model reference manual. Note du pôle modélisation 11, Institut Pierre-Simon Laplace.

Maslowski, W., Marble, D., Walczowski, W., Schauer, U., Clement, J. L., Semtner, A. J., 2004. On climatological mass, heat, and salt transports trough the barents sea and fram strait from a pan-arctic coupled ice-ocean model simulation. Journal of Geophysical Research 109.

Meredith, M., Heywood, K., Dennis, P., Goldso, L., White, R., Fahrbach, E., Schauer, U., Osterhus, S., 2001. Freshwater fluxes through the western fram strait. Geophysical Research Letters 28, 1615-1618.

Molines, J. M., Barnier, B., Penduff, T., Brodeau, L., Treguier, A. M., Theetten, S., Madec, G., 2006. Definition of the interannual experiment orca025-g70, 1958-2004. LEGI report LEGI-DRA-2-11-2006, available at www.ifremer.fr/lpo/drakkar.

Parkinson, C. L., Cavalieri, D. J., Gloersen, P., Zwally, H. J., Comiso, J. C., 1999. Arctic sea ice extents, areas, and trends, 1978-1996. Journal of Geophysical Research 104(C9), 20837-20856.

Penduff, T., Sommer, J. L., Barnier, B., Treguier, A.-M., Molines, J.-M., Madec, G., 2007. Influence of numerical schemes on current-topography interactions in 1/4 global ocean simulations. Ocean Science 3, 509-524. 
Peterson, B. J., Holmes, R. M., McClelland, J. W., Vorosmarty, C. J., Lammers, R. B., Shiklomanov, A. I., Rahmstorf, S., 2002. Increasing river discharge to the arctic ocean. Science 298, 2171-2173.

Pickard, G. L., Emery, W. J., 1990. Arctic sea. In: Descriptive Physical Oceanography: An Introduction. Elsevier, pp. 219-235.

Proshutinsky, A., Steele, M., Zhang, J., Holloway, G., Steiner, N., Häkkinen, S., Holland, D., Gerdes, R., Köberle, C., Karcher, M., Johnson, M., Maslowski, W., Walczowski, W., Hibler, W., Wang, J., 2001. Multinaional effort studies differences among arctic ocean models. Eos Trans. AGU 82(51), 643-644.

Proshutinsky, A., Yang, J., Krishfield, R., Gerdes, R., Karcher, M., Kauker, F., Köberle, C., Häkkinen, S., Hibler, W., Holland, D., Maqueda, M., Holloway, G., Hunke, E., Maslowski, W., Steele, M., Zhang, J., 2005. Arctic ocean study: Synthesis of model results and observations. Eos Trans. AGU 86(40), 368.

Proshutinsky, A. Y., Bourke, R. H., McLaughlin, F. A., 2002. The role of the beaufort gyre in arctic climate variability: seasonal to decadal limate scales. Geophysical Research Letters 29(23).

Proshutinsky, A. Y., Johnson, M. A., 1997. Two circulation regimes of the wind-driven arctic ocean. Journal of Geophysical Research 102, 12,493-12,514.

Rothrock, D. A., Kwok, R., Groves, D., 2000. Satellite views of the arctic ocean freshwater balance. In: Lewis, E. L. (Ed.), The freshwater balance of the Arctic Ocean. Kluwer Academics, pp. 533-588.

Rothrock, D. A., Yu, Y., Maykut, G., 1999. Thinning of the arctic sea-ice cover. Geophysical Research Letters 26, $3469-3472$.

Schauer, U., Beszczynska-Möller, A., Walczowski, W., Fahrbach, E., Piechura, J., Hansen, E., 2008. Variation of measured heat flow through the fram strait between 1997 and 2006. In: Dickson, R. R., Meincke, J., Rhines, P. (Eds.), Arctic-Subarctic Ocean Fluxes. Springer, pp. 385-404.

Schauer, U., Fahrbach, E., Osterhus, S., Rohardt, G., 2004. Arctic warming through the fram strait: Oceanic heat transport from 3 years of measurements. Journal of Geophysical Research 109.

Schlichtholz, P., Houssais, M. N., 1999. An inverse modelling study in fram strait. part 1: dynamics and circulation. Deep-sea research, Part 2 46, 1083-1135. 
Sciremammano, F., 1979. A suggestion for the presentation of correlations and their significance levels. Journal of Physical Oceanography 9, 1273-1276.

Serreze, M. C., Barrett, A. P., Slater, A. G., Woodgate, R. A., Lammers, R. B., Steele, M., Moritz, R., Meredith, M., Lee, C. M., 2006. The large-scale freshwater cycle of the arctic. Journal of Geophysical Research 111.

Steele, M., Ermold, W., Häkkinen, S., Holland, D., Holloway, G., Karcher, M., Kauker, F., Maslowski, W., Steiner, N., Zhang, J., 2001b. Adrift in the beaufort gyre: A model intercomparison. Geophysical Research Letters 28, 2935-2938.

Steele, M., Morley, R., Ermold, W., 2001a. Phc: a global ocean hydrography with a high quality arctic ocean. Journal of Climate 14, 2079-2087.

Steele, M., Thomas, D., Rothrock, D., 1996. A simple model study of the arctic ocean freshwater balance, 19791985. Journal of Geophysical Research 101, 20,833-20,848.

Steiner, N., Holloway, G., Gerdes, R., Hkkinen, S., Holland, D., Karcher, M., Kauker, F., Maslowski, W., Proshutinsky, A., Steele, M., Zhang, J., 2004. Comparing modeled streamfunction, heat and freshwater content in the arctic ocean. Ocean Modelling 6, 265-284.

Swift, J. H., Aagaard, K., Timokhov, L., Nikiforov, E. G., 2005. Long-term variability of arctic ocean waters : Evidence from a reanalysis of the ewg data set. Journal of Geophysical Research 110.

The DRAKKAR group, 2007. Eddy-permitting ocean circulation hindcasts of past decades. CLIVAR exchanges 42. Thomas, D., Martin, S., Rothrock, D., Steele, M., 1996. Assimilating satellite concentration data into an arctic sea ice mass balance model, 1979-1985. Journal of Geophysical Research 101, 20,849-20,868.

Timmermann, R., Goose, H., Madec, G., Fichefet, T., Ethe, C., Duliere, V., 2005. On the representation of high latitude processes in the orca-lim global coupled sea ice-ocean model. Ocean Modelling 8, 175-201.

Treguier, A. M., Theetten, S., Chassignet, E. P., Penduff, T., Smith, R., Talley, L., Beismann, J. O., Boning, C., 2005. The north atlantic subpolar gyre in four high-resolution models. Journal of Physical Oceanography 35, 757-774. Vinje, T., 2000. Fram strait ice fluxes and atmospheric circulation: 1950-2000. Journal of Climate 14, 3508-3517. 
Woodgate, R. A., Aagaard, K., 2005. Revising the bering strait freshwater flux into the arctic ocean. Geophysical Research Letters 32.

Woodgate, R. A., Aagaard, K., Weingartner, T. J., 2005. Monthly temperature, salinity, and transport variability of the bering strait through flow. Geophysical Research Letters 32. 